NBER WORKING PAPER SERIES

\title{
MEXICAN ENTREPRENEURSHIP: A COMPARISON OF SELF-EMPLOYMENT IN MEXICO AND THE UNITED STATES
}

\author{
Robert Fairlie \\ Christopher Woodruff \\ Working Paper 11527 \\ http://www.nber.org/papers/w11527
NATIONAL BUREAU OF ECONOMIC RESEARCH
1050 Massachusetts Avenue
Cambridge, MA 02138
July 2005

We would like to thank Lori Kletzer, David Neumark and seminar participants at UC Davis and the NBER conference on Mexican immigration from helpful comments and suggestions. Daniel Beltran, Kuntal Das, and Jose Martinez provided excellent research assistance. The views expressed herein are those of the author(s) and do not necessarily reflect the views of the National Bureau of Economic Research.

(C2005 by Robert Fairlie and Christopher Woodruff. All rights reserved. Short sections of text, not to exceed two paragraphs, may be quoted without explicit permission provided that full credit, including (C) notice, is given to the source. 
Mexican Entrepreneurship: A Comparison of Self-Employment in Mexico and the United States Robert Fairlie and Christopher Woodruff

NBER Working Paper No. 11527

July 2005

JEL No. F2, J2

\title{
$\underline{\text { ABSTRACT }}$
}

Nearly a quarter of Mexico's workforce is self employed. But in the U.S. rates of self employment among Mexican Americans are only 6 percent, about half the rate among non-Latino whites. Using data from the Mexican and U.S. population census, we show that neither industrial composition nor differences in the age and education of Mexican born populations residing in Mexico and the U.S. accounts for the differences in the self employment rates in the two countries. Within the U.S., however, the data show self employment rates are much higher in ethnic enclaves. In PUMAS with a high percentage of residents of Latino origin, rates of self employment are comparable to rates among non-Latino whites. The data also indicate that the lack of English language ability and the lack of legal status among Mexican American immigrants helps account for their lower rates of self employment.

\author{
Robert W. Fairlie \\ Department of Economics \\ University of California, Santa Cruz \\ Santa Cruz, CA 95064 \\ rfairlie@ucsc.edu \\ Christopher Woodruff \\ Graduate School of International Relations \\ and Pacific Studies \\ University of California, San Diego \\ La Jolla, CA 92093-0519 \\ cwoodruff@ucsd.edu
}




\section{Introduction}

Mexico is one of the most entrepreneurial countries in the world. Selfemployment or entrepreneurship rate estimates from the OECD (2000) rank Mexico at the top of the list of 28 member countries, the Global Entrepreneurship Monitor (2003) rank Mexico $4^{\text {th }}$ in its listing of 41 countries, and the ILO rank Mexico in the $70^{\text {th }}$ percentile of its list of 74 countries. Estimates from these sources and from the Mexico Census indicate that roughly one fourth of Mexico's workforce is a self-employed business owner. Roughly $10 \%$ of individuals born in Mexico currently reside in the United States. In the U. S., however, rates of self employment among Mexican immigrants are low. The U.S. Mexican immigrant rate of self-employment is only 6 percent -- a rate substantially lower than the national average of 11 percent. This difference between the U.S. and home country self-employment rates for Mexican immigrants appears to be an extreme outlier when examining the relationship across immigrant groups in the United States (see Figure 1). ${ }^{1}$

The difference between the total self employment rate in Mexico of approximately $25 \%$ and the total rate in the United States of approximately $11 \%$ is consistent with worldwide, cross country evidence that shows a strong inverse relationship between income levels and self employment (Gollin 2002). State level data from the population census in Mexico are consistent with this pattern as well, showing an inverse relationship between average wage levels and self employment rates. Gollin (2000) provides a theoretical motivation for this pattern with a version of the Lucas (1978) model showing that self employment rates in an economy are decreasing with the

\footnotetext{
${ }^{1}$ Previous research indicates that home country self employment rates are either positively associated with self employment rates in the U.S. (Yuengert 1995) or that the two are not significantly associated (Fairlie and Meyer 1996).
} 
average productivity of the workforce. Given the higher income levels in the U.S., the higher rate of self employment in Mexico is consistent with this theory.

But, why are self employment rates among Mexican immigrants in the U.S. so much lower than those of non-Latino whites? This comparison creates somewhat of a puzzle because the likelihood of having previous experience in self-employment and the finding of a strong intergenerational link in business ownership suggest that Mexican immigrants should have high rates of self-employment, all else equal. In fact, individuals who had a self-employed parent are found to be roughly two to three times as likely to be self-employed as someone who did not have a self-employed parent (see Lentz and Laband 1990, Fairlie 1999, Dunn and Holtz-Eakin 2000, and Hout and Rosen 2000). ${ }^{2}$ Immigrants are also generally more likely to be self employed than are natives in the United States (Borjas 1986, Yuengert 1995, and Fairlie and Meyer 2003). Estimates from the 2000 U.S. Census indicate that the total immigrant self-employment rate is 11 percent higher than the native self-employment rate.

In this chapter, we explore several possible explanations of the lower rates of self employment among Mexican immigrants in the U.S.. Self employment rates of Mexican immigrants in the U.S. may be lower because the characteristics of migrants to the U.S. differ from those of Mexicans remaining in Mexico. Mexican immigrants, at least as measured using U.S. census data, differ in age and education from the population resident in Mexico (Chiquiar and Hanson 2005). This may be important because age and education have been found to be important determinants of self employment rates in the

\footnotetext{
${ }^{2}$ Additional evidence indicates that business inheritances play only a minor role in contributing to the intergenerational link in business ownership and previous work experience in a family member's business has a large positive effect on small business outcomes (Fairlie and Robb 2003).
} 
United States. Our estimates, however, indicate that age and education explain little of the gap between rates in Mexico and rates among Mexicans in the United States. We also examine the sectoral distribution of the workforce in the two countries. Although the distribution of workers across industries differs among Mexican immigrants in the U.S., all workers in the U.S., and the workforce in Mexico, these differences also do not account for much of the gap in self employment.

Finally, we consider differences between rates of self employment for Mexican immigrants and the total U.S. rate. In contrast, we find that the standard measurable characteristics of Mexican immigrants account for roughly half of the difference in self employment rates for men and the entire difference for women. We then examine possible constraints on entry into self employment among Mexicans working in the United States. We find that Mexican immigrant self-employment rates may be higher for those who reside in the United States legally and are fluent in English, and for men, those who live in ethnic enclaves. Data limitations require that we use different data sets to examine these various factors, so a precise estimate of what self employment rates among Mexican immigrants would be in the absence of the constraints of language ability and legal status is difficult. However, the data suggest that these factors contribute to the low rate of self-employment among Mexican immigrants in the United States.

Why should we be interested in self employment rates in Mexico and among Mexican immigrants in the U.S.? There are several possible answers to this question. Some have argued that entrepreneurship provides a route out of poverty and an alternative to unemployment. ${ }^{3}$ Proponents also note that many disadvantaged groups facing discrimination or blocked opportunities in the wage/salary sector have used

\footnotetext{
${ }^{3}$ See Glazer and Moynihan (1970), Light (1972, 1979), Sowell (1981), and Moore (1983).
} 
business ownership as a source of economic advancement. Self-employed business owners may also gain political influence comes with success in small business (Brown, Hamilton, and Medoff 1990).

Whether or not self employment represents a path to economic progress for Mexicans in the U.S., the data suggest that a substantial part of the gap in self employment rates in the U.S. is caused by constraints on entry into a given worker's sector of choice. This implies some efficiency loss, though we cannot estimate to size of that loss using our data. Low wages in Mexico, on the other hand, not only increase the percentage of the workforce working in self employment, but also increase the flow of workers to the U.S. (Hanson and Spillemburgo 1999).

\section{Data}

Our data for the United States come from the 2000 Public Use Microdata 5Percent Sample (PUMS), and our data for Mexico are a 50 percent random draw from the 10 percent extended survey sample of the 2000 Mexico Census. There are some differences in the two census surveys, which should be taken into account when interpreting the results. The U.S. census asks individuals about average hours worked over the preceding year and annual income. The Mexican census asks individuals if they worked in the week prior to the survey, and what their earnings were that week. Additionally, categories of responses for questions sometimes differ, For example, the categories for marital status in Mexico include "live with partner without being married," whereas the U.S. census does not include this possibility. However, overall the differences appear to be modest, and the data are roughly comparable. 
In the U.S. Census, self-employed workers are defined as those individuals who identify themselves as mainly self-employed in their own not incorporated or incorporated business on the class of worker question. ${ }^{4}$ Self-employed workers in the Mexico Census are those who report themselves as employers or workers for their own account in the week preceding the survey.

In our main sample, we include only individuals ages 16-64 who usually worked at least 35 hours per week during the year and are employed in the survey week in the U.S. Census. For Mexico, we include individuals ages 16-64 who worked at least 35 hours in the survey week. In some tables, we include non-workers to address issues of labor force selection. We also create similar industry and education classifications using the two Censuses. Both Censuses use the NAICS industry categories.

The important comparisons in the paper are made between Mexicans resident in Mexico, Mexican immigrants in the U.S., and the overall population in the U.S. For the U.S. sample of Mexican immigrants, we include only immigrants who arrived when they were at least 12 years old, representing 86 percent of all immigrants. This restriction ensures that our sample of Mexican immigrants was raised in Mexico, and thus potentially exposed to the higher rates of business ownership in that country. These Mexican immigrants also participated in the Mexican educational system.

\section{Self-Employment Rates and Industry Composition Differences}

Mexican immigrants in the United States have substantially lower rates of selfemployment than Mexico residents. As reported in Table 1, estimates from the Mexican Census indicate that 25.8 percent of the male, full-time, labor force and 17.0 percent of

\footnotetext{
${ }^{4}$ Unpaid family workers are not counted as self-employed.
} 
the female labor force are self-employed business owners. In contrast, only 6.0 and 6.1 percent of male and female Mexican immigrants, respectively, are self-employed. The disparities in business ownership rates between Mexico residents and U.S. Mexican immigrants are somewhat smaller when we exclude agriculture. However, nonagricultural self-employment rates still differ by nearly 16 percentage points for men and slightly more than 10 percentage points for women. These differences are consistent with broader cross country patterns.

Self-employment rates are notably higher in Mexico than in the United States. The U.S. male self-employment rate is 11.1 percent and the U.S. female self-employment rate is 5.6 percent. The differences in rates raise the possibility that self employment is a different phenomenon in the two countries. However, an examination of earnings distributions suggests that this is not the case. Figures 2 and 3 report non-zero log earnings distributions in the self-employed and wage/salary sectors in the United States and Mexico. ${ }^{5}$ Although earnings are considerably lower in Mexico, the approximate shape and location of distributions are comparable. In both countries, the tails of the distribution are fatter for the self employed than for wage workers and the selfemployment earnings distribution is slightly to the right of the wage/salary earnings distribution. ${ }^{6}$ Although not reported, the comparison of earnings distributions is also similar for Mexican immigrants in the United States.

Returning to rates and focusing on the U.S. experience, Mexican immigrants have rates of business ownership that are notably lower than the national level for men, but are slightly higher for women. The self-employment rate of Mexican immigrant men is 6.0

\footnotetext{
${ }^{5}$ The shapes and comparisons of the distributions are similar if we include zero earnings observations. ${ }^{6}$ Separate estimates by gender reveal a self-employment earnings distribution shifted more to the right relative to the wage/salary earning distribution for men and to the left for women in both countries.
} 
percent compared to a U.S. total rate of 11.1 percent. Interestingly, Mexicans born in the United States have roughly similar rates of self-employment rates as Mexican immigrants for men, and native-born Mexicans have lower rates of self-employment than Mexican immigrants for women. These results are surprising because the native-born Mexican population in the United States is more educated and wealthier than the Mexican immigrant population. Overall, these estimates set the stage for the following analysis. We are interested in answering the question of whether factors other than the level of development of the economy contribute to the higher rates of self-employment in Mexico compared with rates for Mexican immigrants in the United States. We will first examine how much of this difference is explained by differences in the sectoral breakdown of the two economies, or differences in sectors in which Mexican immigrants are employed. Next, we consider the impact from differences in measurable characteristics—education, age, marital status and the number of children—of the Mexican immigrant population compared to the population resident in Mexico.

\section{Industry comparison}

Table 2A presents the distribution of employment of males across 14 major sectors of the economy, as well as self employment rates in each sector. The data are shown for the labor force by sector in Mexico, for Mexican immigrants in the US, for Mexicans born in the United States, and for the entire U.S. labor force. We use 14 major sectors based on US census classifications, though we combine armed forces and public administration and separate transportation from utilities. The top half of the table shows the employment distribution, and the bottom half the self employment rates. A similar breakdown for females is shown on Table 2B. 
Comparing first the structure of the male labor force in Mexico and in the United States (columns 1 and 4), it is apparent that agriculture occupies a much larger part of the Mexican labor force (17.1 percent vs. 2.6 percent in the US) while finance, information, professional and education/health services occupy a larger part of the US workforce (10.6 percent in Mexico vs. 27.0 percent in the United States). But aside from these shifts, the most striking aspect of the data is the similarity of the structure of employment in Mexico and the US. In construction, manufacturing, trade (retail and wholesale combined) and transportation, the percentage of the workforce employed in the two countries is quite similar.

The bottom half of Table 2A shows rates of self employment at the sectoral level for the same four groups of workers. On the whole, rates of self employment are much higher in Mexico than in the US-25.8 percent vs. 11.1 percent. The most important differences in self employment rates between the two countries are in manufacturing, trade, other services and the arts, entertainment and recreation sector. The latter includes employment in hotels and restaurants, while other services includes domestic household workers. Rates of self employment in the two countries are much more similar in construction, and the higher end service sectors (finance, professional, education/health). ${ }^{7}$

The data for females on Table 2B show that the differences between the distribution of employment in Mexico and the U.S. (columns 1 and 4) are much greater for females than for males. A much larger share of the female workforce in Mexico is found in manufacturing, trade and other services, and much less employment is found in

\footnotetext{
${ }^{7}$ In the United States, the detailed industries with the largest concentrations of self-employed men are construction (31.4 percent), landscaping services (14.9 percent), auto repair (6.4 percent), restaurants (5.3 percent), truck transportation (4.3 percent), and crop production (4.2 percent). In Mexico, the most common detailed industries are crop production (37.5 percent), building construction (7.7 percent), retail sales of food products (6.7 percent), repair services (5.8 percent), and ground transportation (3.2 percent).
} 
education/health services as well as finance and professional services. As with males, the data on the lower part of Table 2B show that differences self employment rates are notably higher in manufacturing, trade and the art, entertainment and recreation sectors. Notably, self employment rates in other services are actually lower in Mexico than in the United States. $^{8}$

How much of the difference between self employment rates in Mexico and the US is explained by sectors in which workers are employed? For example, does the relatively larger share of Mexican employment in agriculture, where self employment rates are high even in the US, explain a substantial part of the difference in self employment rates between the two countries? The answer is that the sectoral composition explains only a small part of the overall difference in self employment rates. Taking the rates of self employment at the industry level in the US and applying them to the sectoral distribution of the labor force in Mexico, we obtain a rate of self employment of 14.4 percent for men. That is, if self employment rates within each sector in Mexico were identical to the rates in the U.S., we would expect a rate of self employment in Mexico roughly 3 percentage points higher than that found in the U.S. because more employment is concentrated in high self employment sectors.

Hence, only roughly 3 percentage points of the almost 15 percentage point difference in male self-employment rates is explained by differences in the allocation of labor across sectors. And indeed, all of this is attributable to the larger share of employment in agriculture in Mexico. For non-agricultural employment, the rate of self

\footnotetext{
${ }^{8}$ The most common detailed industries for self-employed women in the United States are private households (24.0 percent), child day care services (16.9 percent), services to buildings (7.3 percent), restaurants (7.1 percent), and beauty salons (5.3 percent). In Mexico, the most common detailed industries are retail sales of food products (21.5 percent), food preparation (12.0 percent), crop production (9.9 percent), domestic service (7.8 percent), and retail sales of clothing (5.8 percent).
} 
employment in the US is 10.6 percent, while the projected rate of self employment in the US given the distribution of the labor force in Mexico is 10.7 percent. Thus, taking the US rates of self employment as a standard, we find that sectoral differences do little to explain the higher rates of self employment in Mexico. Rather, the higher overall rate is driven by higher rates within given sectors, consistent with the models that focus on differences in the levels of workforce productivity.

The results for women are similar. Using the U.S. self-employment rates at the industry level and the sectoral distribution of the labor force in Mexico, we obtain a rate of self employment of 7.6 percent for women. Thus, only 2 percentage points of the 9.4 percentage point gap in female self-employment rates is explained by differences in the allocation of labor across sectors.

The data on Tables 2A and 2B also allow us to say something about the process of assimilation of Mexican immigrants in to the US economy. Column 2 of Tables 2A and 2B shows the male and female sectoral division of labor and the rates of self employment of first generation Mexican immigrants in the US, those born outside of the U.S. and arriving after reaching age 12. Columns 3 of the same two tables show the data for US natives of Mexican descent. Among first generation immigrants, the distribution of employment across sectors differs from both the distribution in Mexico and the distribution in the US. Recent male migrants are much more likely to be employed in construction and arts, entertainment and recreation (restaurants and hotels) than are either those residing in Mexico or the US population as a whole. First generation females are more likely to be employed in manufacturing and arts, entertainment and recreation than are either females in Mexico or the entire female labor force in the US. Compared with 
the US labor force as a whole, males and especially females are much less likely to be found in education/health services. Somewhat surprisingly, the percentage of employment in professional services is as high among first generation Mexicans as it is among the labor force as a whole.

Self employment rates among first generation Mexicans are far below those in Mexico and, for males at least, far below those for the population as a whole in the U.S. The sectoral distribution of employment does not explain the gap between migrants and the population as a whole for males. Indeed, first generation male migrants from Mexico tend to be concentrated in industries with high rates of self employment overall in the U.S. Given the industries in which they work, Mexican males would have an overall self employment rate of 14.4 percent (12.8 percent if agriculture is excluded), compared to an overall rate in the U.S. of 11.1 percent (10.6 percent without agriculture). Recent female immigrants have rates of self employment very similar to the females in the U.S. as a whole, though the data on Table 2B suggest that this is due in part to their being overrepresented in the other services category, where rates of self employment are high.

Among those of Mexican descent born in the US, the sectoral distribution of employment is very similar to the US as a whole for both males and females. Among this group, however, rates of self employment are lower in every sector for both males and for females, compared to the U.S. labor force as a whole. Hence, while first generation females have self employment rates comparable to the overall U.S. population, females of Mexican descent born in the U.S. have markedly lower rates of self employment.

\section{Are Mexican Immigrants Different than Mexico Residents?}


We next turn to an examination of the characteristics of Mexicans resident in Mexico and Mexican immigrants in the US. Previous research using the 1990 and earlier Censuses (Feliciano 2001; Chiquiar and Hanson, 2003) indicates that recent Mexican immigrants to the U.S. are more educated than residents of Mexico. The 2000 census data reported in Table 3 indicate a similar picture. We continue to report estimates for U.S. natives of Mexican descent and the entire US population 16-64 years old for comparison purposes, and we include the full sample of all individuals ages 16-64 instead of conditioning on full-time employment. Despite the fact that a larger portion of Mexican immigrants have no schooling (10.0 percent vs. 6.0 percent for males), Mexican immigrants are less likely to have nine years or less of schooling, and more likely to have 10-15 years of schooling, than are Mexicans resident in Mexico. This pattern holds for both males and females (see columns 1 and 2 of Table 3). Male immigrants are less likely to have 1-4 years of schooling (6.5 percent vs. 14.8 percent of the population of similar age in Mexico) and less likely to have 7-9 years of schooling (19.3 percent vs. 26.3 percent). Among males, 38.9 percent of immigrants have 10-15 years of schooling while only 22.4 percent of the population resident in Mexico has 10-15 years of schooling. However, Mexicans resident in Mexico are more likely to have a college or graduate degree (9.3 percent for males and 6.5 percent for females) than are Mexican immigrants in the United States (3.3 percent for males and 3.6 percent for females). Qualitatively, the same general patterns hold when the sample is limited to those in the labor force.

There are some differences in age distribution of Mexican residents and Mexican immigrants as well, with Mexican immigrants to the US being somewhat older on average than Mexicans remaining in Mexico. Table 4 reports estimates for a comparison 
of age distributions in the two countries. The most notable difference between the age distribution of Mexican resident in Mexico and Mexican immigrants in the U.S. is that the latter are much less likely to be 16-19 years of age. After accounting for the difference in the mass in this age range, there are essentially no differences in the proportion of the population in any of the 5-year age ranges above age 45 for either males or females. For both males and females, a larger part of the immigrant population is between the age of 25 and 45. On the whole, then, immigrants are slightly older than residents of Mexico, but this is driven entirely by under representation of the 16-19 year old age group.

When the sample is limited to those participating full time in the labor force, the age differences among males are slightly smaller, while those for females are slightly larger. For example, 23.5 percent of males in the labor force in Mexico are 16-24 years of age, while 19.5 percent of Mexican immigrants are in that age range. For females, 30.5 percent of those in Mexican labor force and only 13.4 percent of immigrants in the labor force are 16-24 years old.

The available data suggest there are no significant differences between migrant sending households and other households in Mexico with respect to the self employment of household members. Data from the 2000 Mexican Population Census indicate that sending households are slightly more likely to have any member self employed (34\% vs. $32 \%$ ), but no more likely to be headed by someone who is self employed (29\% in either case). The census data do not contain information on households who moved in their entirety before the census was conducted. 


\section{The Determinants of Self-Employment in Mexico and the United States}

Do the differences in the education and age patterns of migrants explain part of the higher self employment rates in Mexico? We explore this question in two steps. First, we estimate regressions of the worker characteristics on self employment status in Mexico and the US. We then combine the Mexican regressions with the characteristics of migrants in the US to estimate what the self employment rates of migrants would be were they working in Mexico. Tables 5A and 5B show regressions for self employment status in Mexico and the US for males and females from a linear probability model. The right hand side variables measure age (nine dummy variables with 16-19 years old being the base group), education (nine dummy variables with no schooling being the base group), the number of children under 18 in the person's household and a dummy variable indicating whether the individual is married. ${ }^{9}$ The first two columns for each gender show results from the Mexico and the third and fourth columns show results from the US. For both countries, we first report results for the entire sample and then for the sample restricted to non-agricultural activities.

The industry breakdown on Table 2 showed that for men agriculture absorbs a much larger share of the labor force in Mexico than in the US. The differences between the determinants of self employment status in agriculture and other activities are evident from comparing the two regressions for males. Education, defined as described in Table 3, is negatively associated with self employment beyond 4 years of schooling in the full sample. Males with high school complete are 6 percentage points less likely to be self

\footnotetext{
${ }^{9}$ The reported U.S. coefficients do not include ethnic, race and immigrant dummies for comparability with the Mexico estimates. Estimates for the age, education, marriage, and children coefficients are fairly similar after including these controls.
} 
employed than males with no schooling. This relationship reflects the high rates of self employment and low levels of schooling among the agricultural labor force. In the nonagricultural sector, the association between education and self employment is very small and positive at least over some ranges. Those with a high school education are 1.4 percentage points more likely to be self employed than those without any schooling. For females, there is a very strong negative association between self employment and education even in non-agricultural activities. Females with high school complete are 19.5 percentage points more likely to be self employed in the full sample and 18 percent more likely to be self employed in the non-agricultural sector.

The effect of education on self employment is markedly different in the US, especially for females (see columns 3 and 4 for each gender). In the US, the probability of being self employed is increasing in education for males, and decreasing very slowly for females through the high school education level. While the effects of education in the U.S. appear very small in absolute terms, for males at least they are not so trivial relative to the overall self employment rate of 11.1 percent. A male with a college degree is 3.5 percentage points more likely to be self employed than is a male without schooling; a female with a college degree is 1.3 percentage points less likely to be self employed. The effect of education changes only very slightly when agriculture is excluded from the U.S. sample.

In all reported regressions, self employment increases steadily in the age of the individual for males. For females, the rates are flat over the first two age ranges, and then increasing beyond age 24. The effect of age on self employment is larger in Mexico than in the United States in absolute terms. Relative to the overall levels of self employment, 
age also has a much larger effect in Mexico among females, and a slightly larger effect in Mexico among males. The strong positive relationship between age and selfemployment, especially in Mexico, is evident in Figures 1A and 1B.

Being married and having more children make self employment more likely for both genders in both countries. The effects are generally not large. Among females, the effect of being married is much larger in Mexico (about 10 percent points), while among males the marriage effect is twice as large in the U.S. Each additional child increases the likelihood of self employment by a fifth to a half of a percent in Mexico, and by a third to a half of a percent in the U.S. Recall, however, that Table 5 is measuring self employment conditional on being in the labor force, and hence indicates only a part of the effect being married with children has on self employment. In Mexico, both being married and having children are associated with higher levels of labor force participation among males and lower levels of labor force participation among females.

The Mexican data allow us to separate self employed workers working by themselves from employers. The majority of Mexican self employed (88 percent of males and 89 percent of females) work by themselves. The percentage of the labor force which is an employer in Mexico (3.1 percent for males and 1.9 percent for females) is close to the percentage of the Mexican labor force which is self employed in the U.S. (4.6 percent for males and 4.2 percent for females). In Table 6, we explore differences in the association between education, age, marital status and children on status as an own account worker and an employer.

In the case of education, the regressions indicate very significant differences in these effects. While education is strongly negatively associated with being an own 
account worker for both males and females, education is positively associated with being an employer for both genders. Relative to the proportion of the labor force which is an employer, the positive effect of education on being an employer is large. Males (females) with some college are almost 6 percent (3 percent) more likely to be an employer than males (females) without schooling. The U.S. census data do not allow us to separate own account workers from employers. But the Mexican employer regressions are similar to the U.S. self employment status regressions, especially for males. Own account status in Mexico appears to be driven by a different dynamic than either employer status in Mexico or self employment in the U.S.

Overall, we find both similarities and dissimilarities between the processes generating self-employment in Mexico and the United States. The differences are clearest among the own account workers. Across regions within Mexico, income levels measured by wage rates are negatively correlated with own account workers as a percetage of the workforce, but positively associated with employers as a percentage of the workforce. The regressions on the determinants of self employment status, then, are consistent with the differences in income levels being the primary driver of differences in self employment rates between the U.S. and Mexico.

\section{Predicted Self-Employment Rates in Mexico and the United States}

Decomposition of the Mexico/U.S. gap in self-employment

We now ask whether differences in the measured characteristics of workers in various groups explain differences in self employment rates. We examine this question from three different perspectives. First, we ask whether characteristics of the workforce 
have any impact on the overall self employment rates in the U.S. and Mexico. We next ask whether the characteristics of Mexican immigrants relative to those remaining in Mexico explain differences in self employment rats of Mexican immigrants in the U.S. and Mexican remaining in Mexico. Finally, we ask whether difference in characteristics of Mexican immigrants in the U.S. and other workers in the U.S. explain any part of the gap between Mexican and overall self employment rate in the U.S.

Tables 7A and 7B report estimates of predicted self-employment rates using coefficient estimates for Mexico and the United States reported in Table 5 and average characteristics of workers in the U.S. and Mexico. For both men and women, predicted self-employment rates using the U.S. coefficients are substantially lower than those using the coefficients from Mexico. In fact, in every case, the difference between predicted self-employment rates in Mexico and the United States after switching characteristics of the working population is larger than the actual difference between Mexico and U.S. selfemployment rates. This finding suggests that the large gaps between levels of selfemployment in Mexico and the United States are entirely due to differences in the structures of the economy and would be even larger if not for the favorable characteristics of the U.S. population -- mainly being older and more educated on average.

\section{Predicted self-employment rates in Mexico}

What next ask what the self employment rate of Mexican immigrants would be if they had remained in Mexico. Using the regression coefficients for self employment status in Mexico, we calculate the predicted probability of self employment for each immigrant, and then take a weighted average of those predicted values. We use the 
regressions reported on Table 5 to estimate the probability of self employment given some set of characteristics $x$. The level of self employment in Mexico can then be written as a function of the determinants of self employment and the distribution of those determinants:

$g^{\text {Mex }}(s e)=\int f(s e \mid x) h(x \mid i=\operatorname{Mex}) d x$

where $x$ represents the characteristics determining entry into self employment and $h(x \mid i=M e x)$ the distribution of those characteristics over the population 16-64 years of age resident in Mexico. Ignoring changes in the determinants of selection into self employment that might be caused by the returning population, we can then substitute the characteristics of Mexican immigrants in the U.S. for those in Mexico:

$$
g_{U S}^{\text {Mex }}(s e)=\int f(s e \mid x) h(x \mid i=U S) d x
$$

This calculation presumes that individuals participating in the labor force in the U.S. would also participate in Mexico, and similarly for those not participating. Labor force participation rates appear to differ somewhat between the two countries, being higher in the U.S. for females born in Mexico and higher in Mexico for males born in Mexico. ${ }^{10}$ For example, the female labor force participation rate among Mexican immigrants in the 2000 U.S. census is 39.2 percent, compared with a rate of 33.0 percent among females in the Mexican census. The full time participation rate, defined as being in the labor force and working 35 hours or more per week, is 28.1 percent in the US and 23.6 percent in Mexico for females. For males, the overall (full time) rates for males are

\footnotetext{
${ }^{10}$ Chiquiar and Hanson (2003) show much higher rates of labor force participation among Mexican immigrants in the U.S. using 1990 census data. It appears from their discussion that they do not condition on working in the week prior to the survey, as we do here.
} 
70.4 percent (61.5 percent) in the US and 77.8 percent (67.7 percent) in Mexico. ${ }^{11}$ The lower rates in the U.S for males may result from our defining participation as working in the week prior to the survey, and their concentration in industries such as construction, where employment is more variable across time.

We can take into account differences in labor force participation rates by simply modeling entry into self employment over the entire population, regardless of whether they participate in the labor force or not. Alternatively, given linear models, we can equivalently first model labor force participation and then model entry into self employment conditional on being in the labor force. That is:

$g^{M e x}(s e)=\iint r(I f p \mid y) s(y \mid i=M e x) d y \quad f(s e \mid x) h(x \mid i=M e x) d x$ where $y$ represents the characteristics determining labor force participation and $s(y \mid i=M e x)$ the distribution of those characteristics over the population 16-64 years of age resident in Mexico. As above, we can project the self employment rates of Mexican immigrants residing in the US were they to return to Mexico by using the distribution of characteristics of immigrants in the US:

$g_{U S}^{M e x}(s e)=\iint r(l f p \mid y) s(y \mid i=U S) d y \quad f(s e \mid x) h(x \mid i=U S) d x$.

In reporting the results of this exercise, we normalize the probabilities of entry into the labor force to 1 when estimating the expected self employment rates, so that the reported self employment rates are comparable to those reported in Table 1 . That is, we estimate self employment as a percentage of the labor force, using the projected labor force participation as a weight.

\footnotetext{
${ }^{11}$ Some of the difference between US and Mexican labor force participation rates may be due to differences in the survey questions. The Mexican census asks about employment during the week before the survey. The US census asks about normal hours over the prior year and activity in the current week.
} 
For males, the overall punch line is that the U.S. immigrants would be expected to have self employment rates very similar to those in the Mexican labor force. Given the measured characteristics, Mexican immigrants residing in the U.S. would be expected to have slightly higher full time labor force participation rates (71.1 percent vs. 67.7 percent), but a slightly lower expected self employment rate conditional on being in the labor force (24.9 percent vs. 25.2 percent). Combining labor force participation and self employment, we find that if immigrants in the U.S. were returned to Mexico, their self employment rates would be almost identical to those of males actually in the labor force in Mexico, 25.7 percent.

The differences for females are slightly larger. Without conditioning on labor force participation, the immigrant population would be expected to have self employment rates of 24.6 percent, higher than a projected rate of 22.1 percent for the entire female population resident in Mexico. Labor force participation rates would be expected to be lower given the characteristics of the immigrant population, however-21.7 percent compared with 23.6 percent among females resident in Mexico. Accounting for expected labor force participation, the projected self employment rate for females with measured characteristics of immigrants resident in the US would be 20.3 percent, significantly higher than the 17.0 percent rate among females resident in Mexico. ${ }^{12}$

Thus, for females, neither the lower labor force participation rates nor the higher self employment rates are the result of differences in characteristics of the immigrant

\footnotetext{
${ }^{12}$ A part of the higher projected self employment rate is due to the higher marriage rate among immigrant females (69 percent) compared with females in Mexico (50 percent). The Mexican census includes a category of "live with spouse in free union." About 10 percent of females in Mexico give this response, which we have counted as unmarried. When we categorize these females as being married, the predicted self employment rate of the immigrant population is $19.5 \%$ rather the $20.3 \%$ when this response is categorized as unmarried.
} 
population. For males, the characteristics of immigrants suggest they would have even

higher labor force participation rate in Mexico than the Mexican residents do. ${ }^{13}$

\section{Predicted self-employment rates of Mexican immigrants in the United States}

In the previous section, we compared the characteristics of Mexican immigrants with residents of Mexico, using the structure of labor markets in Mexico. To understand how self employment rates among Mexican immigrants compare to what would be expected given the characteristics of the U.S. labor market, we now turn to a comparison of Mexican immigrants with other participants in the U.S labor market. Mexican immigrants may possess characteristics that are associated with even lower levels of selfemployment in the United States than those possessed by the U.S. populations as a whole. A younger and less-educated Mexican immigrant working population may explain why self-employment rates for this group, at least for men, are lower than the U.S. total.

To investigate this issue further, we calculate predicted self-employment rates for Mexican immigrants using the U.S. coefficients reported in Table 5. Estimates are reported in Table 8. Mexican immigrants are predicted to have self-employment rates of roughly 8 percent for men and 6 percent for women. The estimates do not differ much when agriculture is excluded.

\footnotetext{
${ }^{13}$ We also examined self employment in the non-agricultural sector, conditional on working in the nonagricultural sector. We do this by defining labor force participation as participation in the non-agricultural workforce, and taking this sample as the sample for the self employment regression as well. The results are quite similar to those reported above. For males, the immigrants in the U.S. have characteristics which would result in higher levels of labor force participation (60.4 percent vs. 56.2 percent) and quite similar expected self employment rates (22.7 percent vs. 22.9 percent). For females, the differences are equally modest, with the projected non-agricultural self employment rate for females 19.8 percent compared with 16.4 percent among females employed in Mexico.
} 
The findings have contrasting implications for men and women. For men, Mexican immigrants are predicted to have lower self-employment rates than the U.S. total suggesting that low levels of education and youth contribute to the lower rates of self-employment. The comparison of predicted self-employment rates indicates that from 2.6 to 2.8 percentage points (or 55.4 to 58.3 percent) of the gaps in self-employment rates are due to differences in measurable characteristics between Mexican immigrants and the U.S. total. ${ }^{14}$ The self-employment rate gaps in the United States are 4.4 and 5.1 percentage points for the non-agriculture and total workforce, respectively.

Among the individual characteristics, roughly 40 percent of the gap is explained by the relatively young Mexican immigrant workforce. As expected, education differences are also important. Low levels of education among Mexican immigrants explain 23.2 to 24.1 percent of the gap in self-employment rates. Finally, Mexican immigrants have more children on average than the U.S. total, which is associated with higher levels of self-employment suggesting that the self-employment rate gap would be 0.4 percentage points larger.

The predicted self-employment rates are higher for Mexican immigrant women than for the U.S. total. This finding suggests that Mexican immigrant women have favorable characteristics, in terms of predicting self-employment, compared to the total U.S. workforce. The similarities between the predicted rates and the actual rates for women also indicate that differences in measurable characteristics are responsible for roughly the entire Mexican immigrant/U.S. total gap in levels of self-employment. The negative relationship between self-employment and education for U.S. women and

\footnotetext{
${ }^{14}$ The estimate is equal to $\hat{\beta}^{\text {U.S. }}\left(\bar{X}^{\text {U.S. }}-\bar{X}^{\text {M.I. }}\right)$, which is the familiar explained component of the gap in a Blinder-Oaxaca decomposition.
} 
relatively low levels of education among Mexican immigrant women contribute to selfemployment rates that are higher for this group than the national average. The relative youth of Mexican immigrant women contributes to the gap, but this is roughly offset by having more children and a slightly higher probability of being married than the U.S. population as a whole.

Returning to our comparison of self-employment rates in Mexico and among Mexican immigrants in the United States, we can use these estimates to calculate a rough estimate of the contribution from Mexico/U.S. differences. The difference in predicted self-employment rates in Mexico and the United States for this group approximates the effect of leaving a country that supports relatively high levels of self-employment to one that does not. Using estimates for all industries we find that the predicted selfemployment for male Mexican immigrants drops from 25.7 percent in Mexico to 8.3 percent in the United States. Female Mexican immigrants are predicted to have a selfemployment rate of 20.3 percent in Mexico and 6.1 percent in the United States. These findings confirm that the large difference in self-employment rates between Mexico and Mexican immigrants in the United States are primarily due to country-level differences in self-employment. A large part of the difference appears to be due to fact that the U.S. economy supports a lower level of self-employment than does the Mexican economy. In sum, the evidence suggests that the difference in the rates of self employment in the U.S. and Mexico overall are not explained by the characteristics of the work forces in the two countries. The analysis suggests that the differences are consistent with the Lucas / Gollin thesis that self employment rates are decreasing in the per capita income of a country. In contrast to these results, the standard measured characteristics of 
workers, such as age, education and family status explain roughly half of the gap between the self employment rate of Mexican immigrants and others in the U.S. economy for men and the entire gap for women. We turn now to an analysis of additional factors that might contribute to differences between Mexican immigrant and U.S. total self employment rates.

\section{7: Some additional evidence on low self employment rates in the U.S.}

In this section, we provide evidence on several factors that might constrain entry into self employment among Mexican immigrants in the United States. We address three issues closely related to migration: enclave effects, English language ability and legal status. We measure enclave effects as the percentage of individuals residing in a Public Use Microsample Area (PUMA) who were born in Mexico. English language ability is self reported in the census. To examine legal status, we use data from the Legalized Population Survey (LPS).

Using a measure of enclave at the SMSA level, Borjas (1986) finds that self employment among Mexican, Cubans, and "other Hispanics" is increasing in the percentage of Hispanics in an SMSA. The effect is larger among the immigrant population than among the population born in the U.S. English language ability has been found to affect earnings in wage labor markets (McManus, Gould and Welch 1983; Dustman and van Soest 2002; Bleakley and Chin 2003). Fairlie and Meyer (1996) find that better command of the English language associated with more self employment among males, while the opposite holds among females. 
The raw data suggest that enclave effects are important. Self employment rates among Mexican-born males and females are higher in PUMAs where a larger percentage of the population is of Latino descent. To see this, we rank the PUMAs according to the percentage of their population which is of Latino origin. The lower quartile of PUMAs have an less than 1.8\% Latino-origin population. The cutoffs for the second and third quartiles are $4.5 \%$ and $15 \%$, respectively. The PUMA at the $90^{\text {th }}$ percentile has almost 34\% population of Latino descent. For males, the self employment rate among the Mexican-born population living in the PUMAS in the three lower quartiles is around $4.4 \%$. There is no clear trend in the rate within the three lower quartiles. The rate among those in the top quartile of PUMAs according to Latino population is 6.6\%. Moreover, the self employment rates are clearly increasing even within the last quartile. Among the Mexican-born residing in PUMAs in the top decile, the rate is 7.3\%; among those in the top percentile (more than $79 \%$ Latino population), the rate is $10.8 \%$. Females have a pattern whish is similar in the direction of the trend, but less pronounced. Those living in PUMAs in the lower three quartiles of Latino-origin population have self employment rates of around $4.4 \%$. Those in the top quartile of PUMAs have self employment rates of 5.8\%. Within the top decile (percentile) of PUMAs by Latino-origin population, the female self employment rate is $5.8 \%$ (6.2\%).

English language ability is also associated with self employment rates among males but not among females. The Census asks member of households where a language other than English is spoken whether they speak English "very well," "well," "not well," or "not al all.” We group the last two categories together as indicating difficulty with English language, and compare people in this group to those who either report that they 
speak only English, or report that they speak English very well or well. Among those with lower English language ability, male self employment rates are 4.7\%; the comparable number among those who speak English well or fluently are $7.3 \%$. The raw differences among females are much smaller. Females with lower language ability have self employment rates of 5.4\%; those with fluency or near fluency have self employment rates of $5.7 \%$.

To see if these raw differences hold up to controlling for other factors such as age and education, we ran probits on self employment status. The regressions include the same basic controls as those reported earlier: education and age categories, marital status and number of children. Table 9 reports results for the English language and enclave variables. The sample for the regression is limited to Mexican immigrants. ${ }^{15}$ For males (Column 1), the data from the 2000 census are consistent with the earlier findings of Borjas and Fairlie and Meyer. For females (Column 3), we find that neither enclave nor command of the English language are associated with higher rates of self employment, results consistent with those reported by Fairlie and Meyer. Relative to the gap between actual and expected self employment rates, the language and enclave effects are large for males. A one standard deviation increase in the percentage of the Latino-origin population in the PUMA (16 percentage points) is associated with an increase in the self employment rate by 0.9 percentage points; fluency or near fluency in English is associated with an increase in self employment rates of 2.0 percentage points.

\footnotetext{
${ }^{15}$ We also looked at English language ability in the sample of all foreign born. For males, the coefficient on English language ability is of a very similar magnitude. Among females, the language coefficient in the larger sample of all immigrants is actually negative and marginally significant, indicating that better English language ability is associated with a $0.7 \%$ lower probability of self employment.
} 
Language ability and enclave effects are likely to interact with one another. In particular, we might expect language ability to be less important for individuals residing in enclaves. Indeed, we find this is the case. The interaction term for the enclave measure and language ability is negative when included in the regressions (Columns 2 and 4). For males, inclusion of the interaction term increases the effect of English language fluency to 2.5 percentage points for males evaluated at the median Latino population (4.4 percent), and the effect of a standard deviation increase in the Latino population in the PUMA to 1.4 percentage points. Among those fluent in English, the enclave effect is cut by two-thirds. For females, including the interaction effects makes the language effect marginally significant. English fluency is associated with a 0.65 percentage point increase in self employment rates at the median Latino density. The effect is smaller in PUMAs with more Latino-origin population, and disappears in the upper quartile of those PUMAs. While these results suggest a correlation between English language ability and self employment, the direction of causation and whether the relationship is driven by an unobserved factor, such as entrepreneurial ability, are difficult to ascertain. ${ }^{16}$

The final explanation we explore here is the legal status of Mexican immigrants. The Bureau of the Census estimates that 3.9 million of the 7.8 million Mexican-born residents of the U.S. are not registered with immigration authorities (Costanzo et al, 2001). Included in this number are many residents who are in the United States legally,

\footnotetext{
${ }^{16}$ One instrument for language ability that has been suggested in the literature is the age of arrival in the United States (Bleakley and Chin, 2003). Because migration to the U.S. might also be seen as a decision endogenous to entrepreneurial ability, this instrument is valid only among a sample of those arriving in the U.S. at a young age- that is, as dependents. Among the sample of those arriving at age 14 or younger, the language and enclave effects are not significant in both linear probability and IV regressions. Hence, we report the language and enclave results as associations rather than causal factors.
} 
but not yet reported in official immigration statistics. ${ }^{17}$ The INS places the number of undocumented Mexican born in 2000 at 4.8 million, and Passel, et al. at 5.3 million. These estimates suggest that half or more of the Mexican born population resides in the U.S. without legal documentation. Legal status may affect the self employment decision through its affect on the ability to access institutions important to entrepreneurs. For example, legal status helps ensure that immigrants have access to the court system, should disputes arise with employees or customers. Legal migrants are more likely to own property which might be used as collateral, and hence have access to credit. On the other hand, legal status may increase employment opportunities and earnings in the wage and salary sector (Kossoudji and Cobb-Clark, 2002).

To see whether legal status affects self employment rates, we use data from the 1990 Census and the Legalized Population Survey (LPS). The LPS interviewed immigrants applying for legal status through IRCA in 1988 and again in 1992. The LPS asked about employment the week before applying for legal status, generally in 1987 or 1988, and again in 1992.The sample includes 892 males and 500 females born in Mexico. The LPS data indicate that the self employment rate of immigrants increased markedly after they were legalized through IRCA. For the full sample of male (female) immigrants, the rate of self employment increased from 4.6\% (3.6\%) in 1989 to 8.3\% (5.1\%) in 1992. Among the Mexican born males, self employment increased over the same period from $3.0 \%$ to $5.6 \%$; among females, self employment increased from $2.2 \%$ to $3.2 \%$. Thus, if half of the resident Mexican-born population lacks legal status, and legal status is associated with a 2.3 percentage point increase in self employment, then rates of self

\footnotetext{
${ }^{17}$ The 3.9 million estimate is part of the "residual foreign-born population.” See Costanzo at al (2001) for details on the estimation.
} 
employment among the Mexican born population might be expected to increase by 1.2 percentage points with legalization of the resident population. The data suggest, then, that legal status may be an important factor in explaining the lower self employment rates among the Mexican born population.

\section{Conclusions}

We have started with the large difference between self-employment rates in Mexico and among Mexican immigrants in the United States and have examined the separate components of this difference. The male and female self-employment rates in Mexico are 25.8 and 17.0 percent, respectively. In comparison, male and female Mexican immigrants in the United States have self-employment rates of only 6.0 and 6.1 percent, respectively. The composition of industries in Mexico and the US explains very little of the difference in self employment rates. Agriculture, a sector with high rates of self employment, occupies a much larger share of the male labor force in Mexico. But large differences in self employment rates remain in the non-agricultural sector. For males, 22.1 percent of the labor force in Mexico is self employed, compared with only 6.2 percent of the immigrant labor force in the US. We find that none of this difference is explained by the sectoral composition of the non-agricultural labor force. Rather, the difference is explained by higher rates of self employment within sectors in Mexico compared to the US.

We also compared the determinants of self-employment in the two countries and found some interesting differences. One example is that the positive relationship between self-employment and age is stronger in Mexico than in the United States. 
Calculating predicted self-employment rates, we also find that the large gaps between levels of self-employment in Mexico and the United States are entirely due to differences in the structures of the economy and would be even larger if not for the favorable characteristics of the U.S. population -- mainly being older and more educated on average. These differences may be due to country-level differences in institutions, production technologies, tax rates, and other economic factors between the two countries.

We next turn to differences in the characteristics of Mexican immigrants in the US compared with the population remaining in Mexico. Consistent with previous research, we show that Mexican immigrants are more likely to have 10-15 years of schooling, and less likely to have levels of schooling lower or higher than this range. We also show that immigrants are older than residents of Mexico. Using a linear model to estimate self employment status in Mexico, however, we find that these differences explain very little of the difference in self employment rates for males and actually increase the differences for females. That is, based on measured characteristics, female immigrants would be expected to have higher rates of self employment than females resident in Mexico, were they to return.

We also calculate predicted self-employment rates for Mexican immigrants using U.S. coefficients and find contrasting results for men and women. For men, Mexican immigrants are predicted to have lower self-employment rates than the U.S. total suggesting that low levels of education and youth contribute to why self-employment is relatively low among Mexican immigrants. We find that more than 50 percent of the U.S. total/Mexican immigrant gap is due to differences in measurable characteristics. In contrast, predicted self-employment rates are higher for Mexican immigrant women than 
for the U.S. total. This finding suggests that Mexican immigrant women have favorable characteristics, in terms of predicting self-employment, compared to the total U.S. workforce and that roughly the entire Mexican immigrant/U.S. total gap in levels of selfemployment is explained by differences in measurable characteristics. We also find some evidence suggesting that for both men and women, Mexican immigrant selfemployment rates may be higher for those who reside in the United States legally and are fluent in English, and for men, those who live in ethnic enclaves. 


\section{Bibliography}

Bleakley, Hoyt and Aimee Chin, 2003, "Language Skills and Earnings: Evidence from Childhood Immigrants,” working paper UCSD.

Borjas, George. 1986. "The Self-Employment Experience of Immigrants." Journal of Human Resources 21(4):487-506.

Chiquiar, Daniel and Hanson, Gordon, 2003, “International Migration, Self-Selection, and the Distribution of Wages: Evidence from Mexico and the United States," working paper, UCSD.

Costanzo, Joe, Cynthia Davis, Caribert Irazi, Daniel Goodkind, Roberto Ramirez, 2001, “Evaluating Components of International Migration: The Residual Foreign Born,” U.S. Census Bureau. (Available at: www.census.gov/population/documentation/twps0061.html .)

Dunn, Thomas A. and Douglas J. Holtz-Eakin. 2000. "Financial Capital, Human Capital, and the Transition to Self-Employment: Evidence from Intergenerational Links," Journal of Labor Economics 18 (2): 282-305.

Dustmann, Christian and Arthur van Soest, 2002, "Language and the Earnings of Immigrants,” Industrial and Labor Relations Review 55:3, pp. 473-492.

Fairlie, Robert W. 1999. "The Absence of the African-American Owned Business: An Analysis of the Dynamics of Self-Employment." Journal of Labor Economics, 17(1): 80108.

Fairlie, Robert W., and Bruce D. Meyer. 1996. "Ethnic and Racial Self-Employment Differences and Possible Explanations," Journal of Human Resources, 31, Fall 1996, pp. 757-793.

Fairlie, Robert W., and Bruce D. Meyer. 2003. "The Effect of Immigration on Native Self-Employment," Journal of Labor Economics. 21(3): 619-650.

Fairlie, Robert W., and Alicia Robb. 2003. "Families, Human Capital, and Small Businesses: Evidence from the Characteristics of Business Owners Survey," Economic Growth Center, Yale University, Center Discussion Paper No. 871.

Feliciano, Zadia, 2001, “The Skill and Economic Performance of Mexican Immigrants from 1910 to 1990,” Explorations in Economic History, Vol. 38, pp. 386-409.

Gollin, Douglas, 2000, “Nobody’s Business but My Own: Self Employment and Small Enterpirse in Economic Development,” working paper, Williams College. 
, 2002, “Getting Income Shares Right”, Journal of Political Economy, Vol.

100(2), pp. 458-474.

Hanson, Gordon and Antonio Spilimbergo, 1999, "Illegal Immigration, Border

Enforcement, and Relative Wages: Evidence rfrom Apprehansions at the U.S. 0 Mexico Border,” American Economic Review, Vol. 89, pp. 1337-1357.

Hout, Michael and Harvey S. Rosen. 2000. "Self-Employment, Family Background, and Race," Journal of Human Resources., 35 (4): 670-692.

Kossoudji, Sherrie A. and Deborah A. Cobb-Clark, 2002, "Coming out of the Shadows: Learning about Legal Status and Wages from the Legalized Population," Journal of Labor Economics, July 20(3): 598-628.

Lentz, Bernard, and David Laband. 1990. "Entrepreneurial Success and Occupational Inheritance among Proprietors," Canadian Journal of Economics, 23, No. 3, pp. 563-579.

Passel, Jeffrey, Randy Capps, and Michael Fix, 2004, "Undocumented Immigrants: Facts and Figures,” working paper, Urban Institute.

Yuengert, Andrew M. 1995. "Testing Hypotheses of Immigrant Self-Employment." Journal of Human Resources 30(1):194-204. 


\section{Home Country vs. U.S. Self Employment Rate}

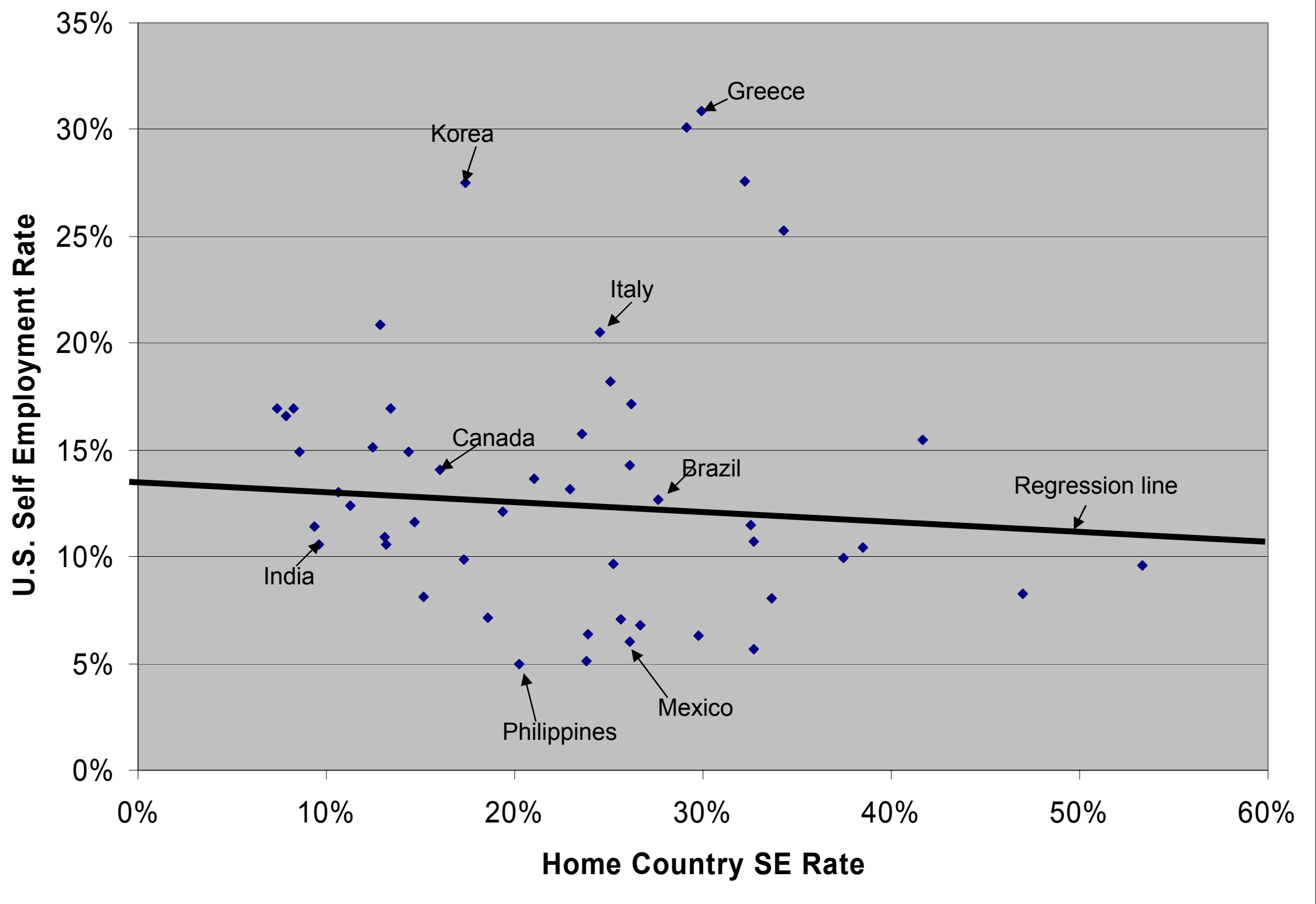


Figure 2
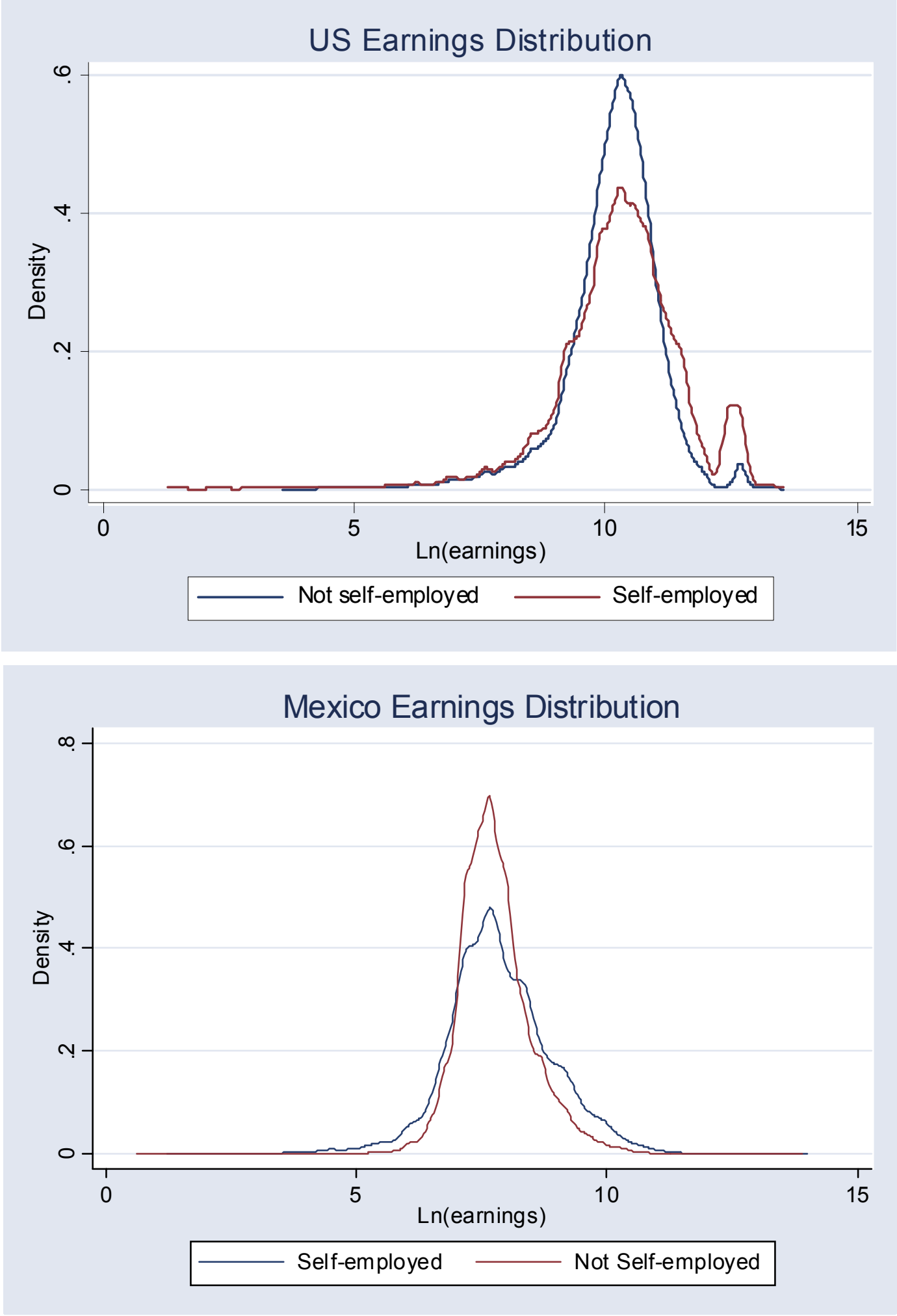
Figure 3A

Educational Regression Coefficients - Men

Includes Agriculture

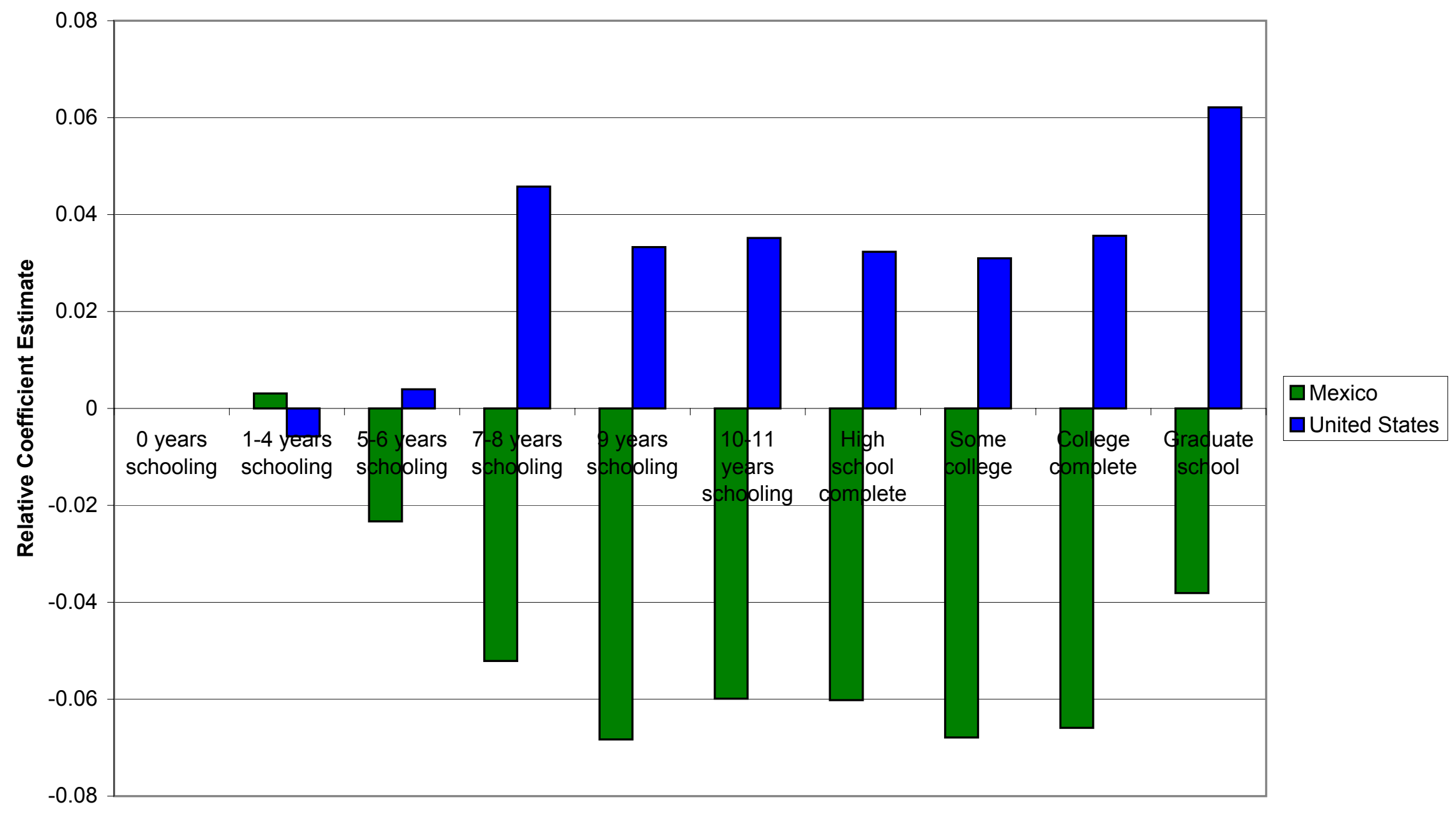


Figure 3B

Educational Regression Coefficients - Women

Includes Agriculture

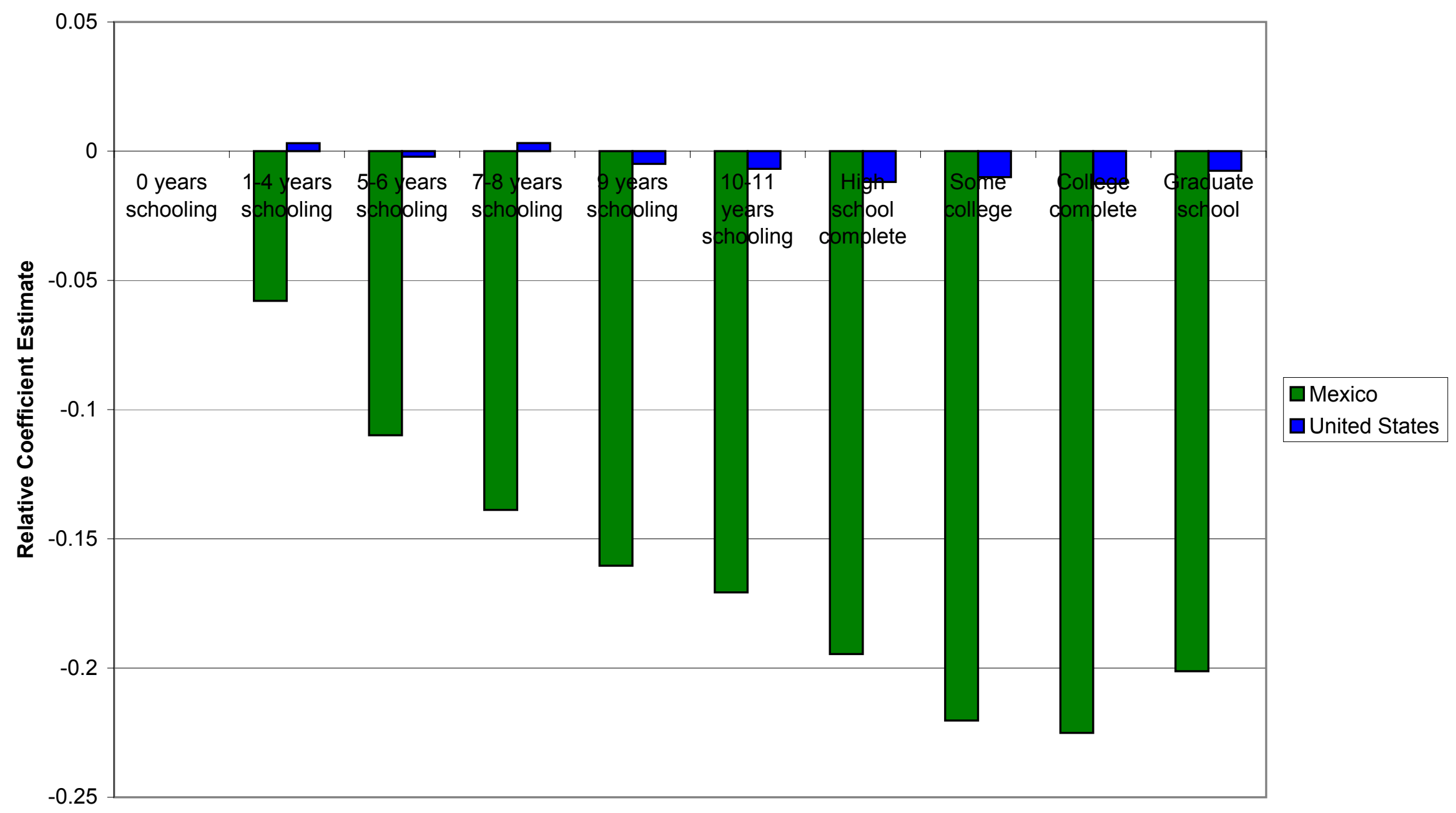


Figure 4A

Male Self-Employment Rates by Age in Mexico and the United States

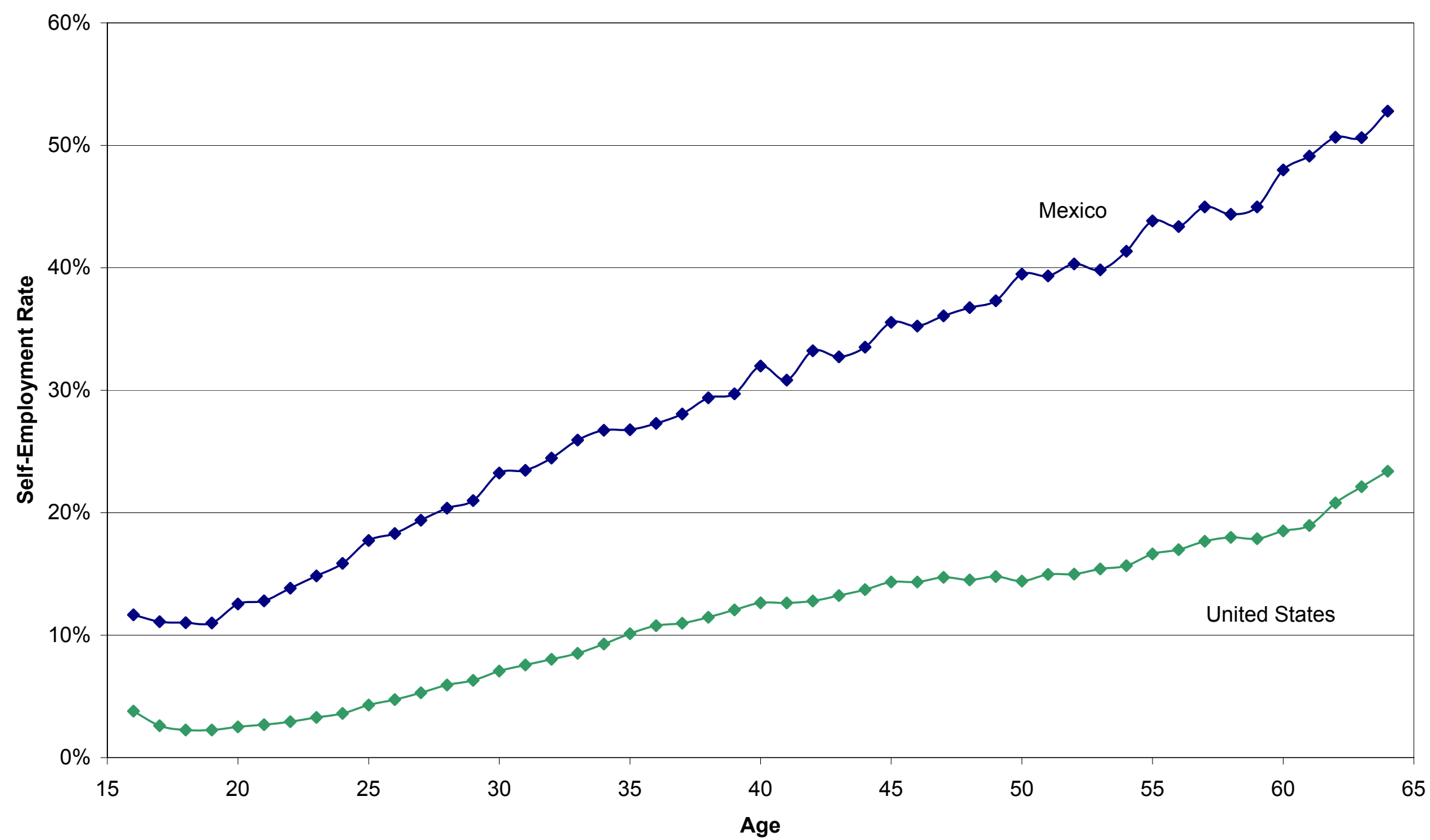


Figure 4B

Female Self-Employment Rates by Age in Mexico and the United States

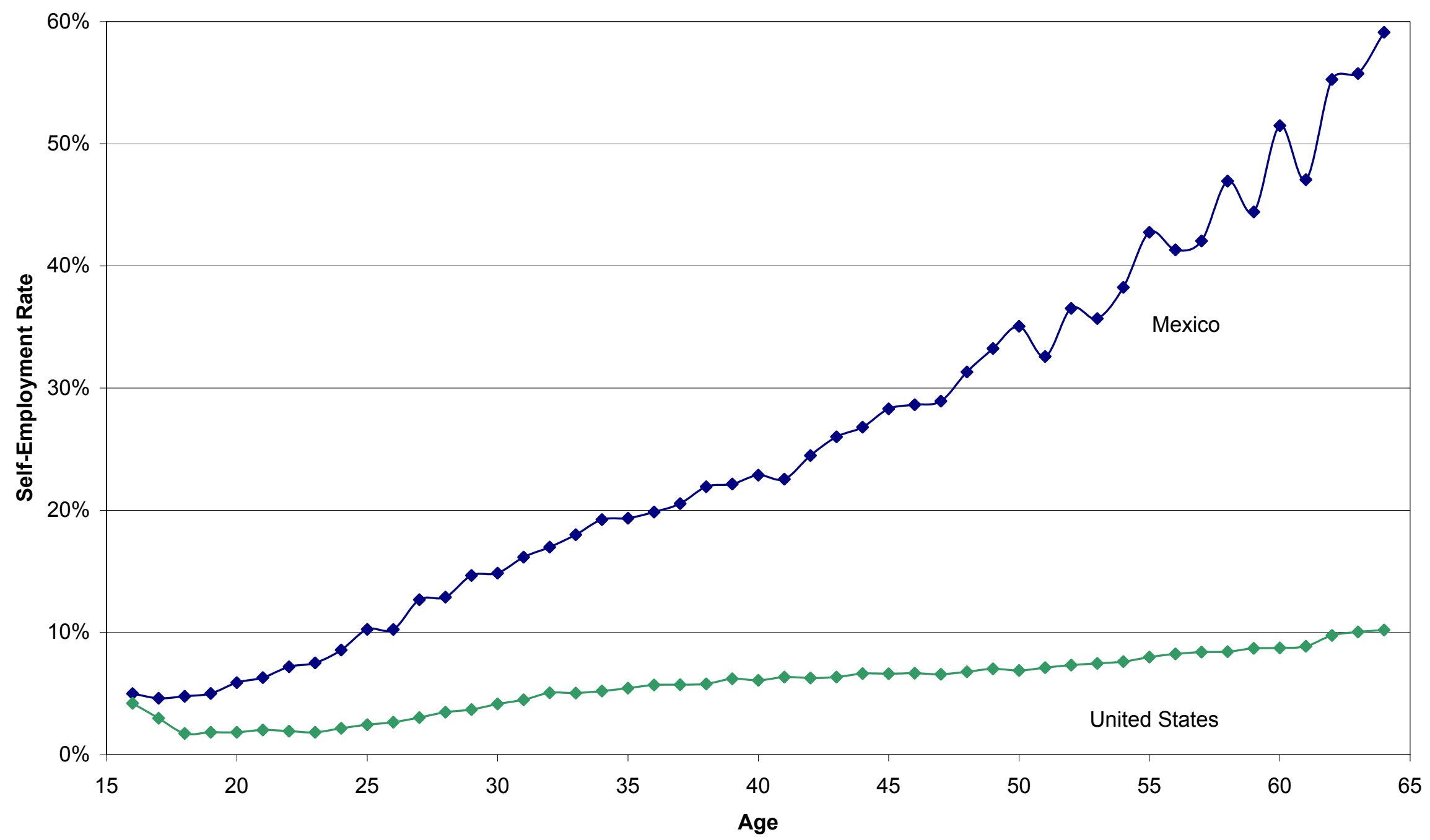




\section{Table 1}

Self-Employment Rates in Mexico and the United States

Mexico Census (2000) and U.S. Census 5\% PUMS (2000)

\begin{tabular}{|c|c|c|c|c|}
\hline & Mexico & $\begin{array}{l}\text { Mexican } \\
\text { Immigrants } \\
\text { in U.S. }\end{array}$ & $\begin{array}{c}\text { Mexican } \\
\text { Natives } \\
\text { in U.S. }\end{array}$ & $\begin{array}{l}\text { U.S. } \\
\text { Total }\end{array}$ \\
\hline \multicolumn{5}{|l|}{ Men } \\
\hline Self-employment rate (non-agriculture) & $22.1 \%$ & $6.2 \%$ & $6.0 \%$ & $10.6 \%$ \\
\hline Sample size & 601,609 & 94,532 & 71,270 & $2,792,824$ \\
\hline Self-employment rate (all industries) & $25.8 \%$ & $6.0 \%$ & $6.0 \%$ & $11.1 \%$ \\
\hline Sample size & 814,729 & 106,006 & 73,928 & $2,893,273$ \\
\hline \multicolumn{5}{|l|}{ Women } \\
\hline Self-employment rate (non-agriculture) & $16.4 \%$ & $6.2 \%$ & $3.4 \%$ & $5.5 \%$ \\
\hline Sample size & 268,259 & 33,987 & 55,095 & $2,079,656$ \\
\hline Self-employment rate (all industries) & $17.0 \%$ & $6.1 \%$ & $3.4 \%$ & $5.6 \%$ \\
\hline Sample size & 285,377 & 35,980 & 55,582 & $2,096,007$ \\
\hline
\end{tabular}

Notes: (1) The sample consists of individuals ages 16-64 who work 35 or more hours per week. (2) All estimates are calculated using sample weights provided by the Census. 
Table 2A

Male Industry Shares and Self-Employment Rates in Mexico and the United States Mexico Census (2000) and U.S. Census 5\% PUMS (2000)

\begin{tabular}{|c|c|c|c|c|}
\hline & Mexico & $\begin{array}{r}\text { Mexican } \\
\text { Immigrants } \\
\text { in U.S. }\end{array}$ & $\begin{array}{c}\text { Mexican } \\
\text { Natives } \\
\text { in U.S. }\end{array}$ & $\begin{array}{l}\text { U.S. } \\
\text { Total }\end{array}$ \\
\hline \multicolumn{5}{|l|}{ Industry Shares } \\
\hline Agriculture/Mining & $17.1 \%$ & $8.7 \%$ & $2.9 \%$ & $2.6 \%$ \\
\hline Construction & $12.5 \%$ & $22.6 \%$ & $13.0 \%$ & $11.8 \%$ \\
\hline Manufacturing & $22.2 \%$ & $22.7 \%$ & $17.5 \%$ & $19.8 \%$ \\
\hline Wholesale Trade & $1.5 \%$ & $4.9 \%$ & $5.4 \%$ & $4.9 \%$ \\
\hline Retail Trade & $13.2 \%$ & $6.1 \%$ & $11.2 \%$ & $9.8 \%$ \\
\hline Trans and Warehousing & $6.6 \%$ & $3.1 \%$ & $6.6 \%$ & $6.1 \%$ \\
\hline Utilities & $0.7 \%$ & $0.3 \%$ & $1.6 \%$ & $1.5 \%$ \\
\hline Information & $1.0 \%$ & $0.7 \%$ & $2.9 \%$ & $3.2 \%$ \\
\hline FIRE & $1.2 \%$ & $1.5 \%$ & $4.0 \%$ & $5.5 \%$ \\
\hline Prof Services & $4.1 \%$ & $9.5 \%$ & $7.7 \%$ & $9.5 \%$ \\
\hline Educ/health Services & $4.3 \%$ & $2.0 \%$ & $8.1 \%$ & $8.8 \%$ \\
\hline Arts, Ent, Rec & $4.2 \%$ & $12.5 \%$ & $6.1 \%$ & $5.4 \%$ \\
\hline Other Services & $6.9 \%$ & $4.6 \%$ & $4.3 \%$ & $4.3 \%$ \\
\hline Public Admin/AF & $4.5 \%$ & $0.6 \%$ & $8.7 \%$ & $6.8 \%$ \\
\hline Total & $100.0 \%$ & $100.0 \%$ & $100.0 \%$ & $100.0 \%$ \\
\hline \multicolumn{5}{|l|}{ Self-Employment Rates } \\
\hline Agriculture/Mining & $43.5 \%$ & $4.3 \%$ & $7.0 \%$ & $32.5 \%$ \\
\hline Construction & $24.0 \%$ & $8.3 \%$ & $13.3 \%$ & $22.7 \%$ \\
\hline Manufacturing & $13.3 \%$ & $1.2 \%$ & $1.6 \%$ & $2.9 \%$ \\
\hline Wholesale Trade & $24.3 \%$ & $3.7 \%$ & $3.6 \%$ & $8.9 \%$ \\
\hline Retail Trade & $38.9 \%$ & $9.1 \%$ & $4.7 \%$ & $10.7 \%$ \\
\hline Trans and Warehousing & $22.7 \%$ & $11.5 \%$ & $6.5 \%$ & $9.2 \%$ \\
\hline Utilities & $2.0 \%$ & $0.0 \%$ & $0.0 \%$ & $0.0 \%$ \\
\hline Information & $8.5 \%$ & $3.6 \%$ & $2.5 \%$ & $4.9 \%$ \\
\hline FIRE & $15.7 \%$ & $7.4 \%$ & $8.4 \%$ & $14.7 \%$ \\
\hline Prof Services & $26.1 \%$ & $12.1 \%$ & $13.8 \%$ & $20.7 \%$ \\
\hline Educ/health Services & $10.0 \%$ & $3.7 \%$ & $2.9 \%$ & $7.2 \%$ \\
\hline Arts, Ent, Rec & $26.1 \%$ & $3.1 \%$ & $4.7 \%$ & $10.5 \%$ \\
\hline Other Services & $34.7 \%$ & $13.6 \%$ & $15.6 \%$ & $19.9 \%$ \\
\hline Public Admin/AF & $1.8 \%$ & $0.0 \%$ & $0.0 \%$ & $0.0 \%$ \\
\hline Total & $25.8 \%$ & $6.0 \%$ & $6.0 \%$ & $11.1 \%$ \\
\hline Sample size & 814,729 & 106,006 & 73,928 & $2,893,273$ \\
\hline
\end{tabular}

Notes: (1) The sample consists of individuals ages 16-64 who work 35 or more hours per week. (2) All estimates are calculated using sample weights provided by the Census. 
Table 2B

Female Industry Shares and Self-Employment Rates in Mexico and the United States Mexico Census (2000) and U.S. Census 5\% PUMS (2000)

\begin{tabular}{|c|c|c|c|c|}
\hline & Mexico & $\begin{array}{r}\text { Mexican } \\
\text { Immigrants } \\
\text { in U.S. }\end{array}$ & $\begin{array}{c}\text { Mexican } \\
\text { Natives } \\
\text { in U.S. }\end{array}$ & $\begin{array}{l}\text { U.S. } \\
\text { Total }\end{array}$ \\
\hline \multicolumn{5}{|l|}{ Industry Shares } \\
\hline Agriculture/Mining & $3.6 \%$ & $4.6 \%$ & $0.8 \%$ & $0.6 \%$ \\
\hline Construction & $0.9 \%$ & $1.2 \%$ & $1.4 \%$ & $1.5 \%$ \\
\hline Manufacturing & $23.4 \%$ & $29.1 \%$ & $10.5 \%$ & $11.7 \%$ \\
\hline Wholesale Trade & $1.0 \%$ & $5.5 \%$ & $2.8 \%$ & $2.6 \%$ \\
\hline Retail Trade & $20.1 \%$ & $8.2 \%$ & $12.1 \%$ & $10.3 \%$ \\
\hline Trans and Warehousing & $1.1 \%$ & $1.5 \%$ & $2.5 \%$ & $2.5 \%$ \\
\hline Utilities & $0.3 \%$ & $0.1 \%$ & $0.7 \%$ & $0.6 \%$ \\
\hline Information & $1.3 \%$ & $1.0 \%$ & $3.3 \%$ & $3.4 \%$ \\
\hline FIRE & $2.1 \%$ & $2.8 \%$ & $9.6 \%$ & $9.7 \%$ \\
\hline Prof Services & $4.6 \%$ & $7.1 \%$ & $7.9 \%$ & $9.1 \%$ \\
\hline Educ/health Services & $14.4 \%$ & $13.4 \%$ & $30.0 \%$ & $31.4 \%$ \\
\hline Arts, Ent, Rec & $8.2 \%$ & $16.4 \%$ & $7.1 \%$ & $6.3 \%$ \\
\hline Other Services & $13.5 \%$ & $7.8 \%$ & $4.0 \%$ & $4.1 \%$ \\
\hline Public Admin/AF & $5.6 \%$ & $1.3 \%$ & $7.4 \%$ & $5.9 \%$ \\
\hline Total & $100.0 \%$ & $100.0 \%$ & $100.0 \%$ & $100.0 \%$ \\
\hline \multicolumn{5}{|l|}{ Self-Employment Rates } \\
\hline Agriculture/Mining & $33.1 \%$ & $2.9 \%$ & $4.8 \%$ & $25.0 \%$ \\
\hline Construction & $10.7 \%$ & $10.0 \%$ & $7.3 \%$ & $14.0 \%$ \\
\hline Manufacturing & $7.9 \%$ & $1.3 \%$ & $1.1 \%$ & $1.8 \%$ \\
\hline Wholesale Trade & $11.8 \%$ & $2.8 \%$ & $1.5 \%$ & $4.8 \%$ \\
\hline Retail Trade & $39.5 \%$ & $9.3 \%$ & $2.7 \%$ & $6.7 \%$ \\
\hline Trans and Warehousing & $5.1 \%$ & $4.4 \%$ & $1.7 \%$ & $3.3 \%$ \\
\hline Utilities & $1.5 \%$ & $0.0 \%$ & $0.0 \%$ & $0.0 \%$ \\
\hline Information & $4.3 \%$ & $0.9 \%$ & $1.7 \%$ & $2.7 \%$ \\
\hline FIRE & $5.4 \%$ & $4.0 \%$ & $3.1 \%$ & $4.8 \%$ \\
\hline Prof Services & $11.9 \%$ & $9.3 \%$ & $6.2 \%$ & $11.4 \%$ \\
\hline Educ/health Services & $4.2 \%$ & $9.2 \%$ & $3.2 \%$ & $3.8 \%$ \\
\hline Arts, Ent, Rec & $28.5 \%$ & $2.9 \%$ & $3.7 \%$ & $6.8 \%$ \\
\hline Other Services & $15.1 \%$ & $25.4 \%$ & $17.4 \%$ & $22.1 \%$ \\
\hline Public Admin/AF & $0.8 \%$ & $0.0 \%$ & $0.0 \%$ & $0.0 \%$ \\
\hline Total & $17.0 \%$ & $6.1 \%$ & $3.4 \%$ & $5.6 \%$ \\
\hline Sample size & 285,377 & 35,980 & 55,582 & $2,096,007$ \\
\hline
\end{tabular}

Notes: (1) The sample consists of individuals ages 16-64 who work 35 or more hours per week. (2) All estimates are calculated using sample weights provided by the Census. 
Table 3

Educational Distributions in Mexico and the United States

Mexico Census (2000) and U.S. Census 5\% PUMS (2000)

\begin{tabular}{|c|c|c|c|c|}
\hline & Mexico & $\begin{array}{r}\text { Mexican } \\
\text { Immigrants } \\
\text { in U.S. }\end{array}$ & $\begin{array}{c}\text { Mexican } \\
\text { Natives } \\
\text { in U.S. }\end{array}$ & $\begin{array}{l}\text { U.S. } \\
\text { Total }\end{array}$ \\
\hline \multicolumn{5}{|l|}{ Men } \\
\hline No schooling & $6.0 \%$ & $10.0 \%$ & $1.7 \%$ & $1.2 \%$ \\
\hline 1-4 Years of school & $14.8 \%$ & $6.5 \%$ & $0.8 \%$ & $0.6 \%$ \\
\hline 5-6 Years of school & $21.3 \%$ & $22.0 \%$ & $2.0 \%$ & $1.7 \%$ \\
\hline 7-8 Years of school & $5.8 \%$ & $9.0 \%$ & $3.4 \%$ & $2.3 \%$ \\
\hline 9 Years of school & $20.5 \%$ & $10.3 \%$ & $5.3 \%$ & $3.3 \%$ \\
\hline 10-11 Years of school & $7.4 \%$ & $15.3 \%$ & $23.6 \%$ & $13.4 \%$ \\
\hline High school graduate & $10.2 \%$ & $15.8 \%$ & $28.1 \%$ & $26.9 \%$ \\
\hline Some College & $4.8 \%$ & $7.8 \%$ & $26.4 \%$ & $27.8 \%$ \\
\hline College Graduate & $4.3 \%$ & $2.0 \%$ & $6.2 \%$ & $14.6 \%$ \\
\hline Graduate School & $5.0 \%$ & $1.3 \%$ & $2.5 \%$ & $8.2 \%$ \\
\hline High school graduate or more & $24.3 \%$ & $26.8 \%$ & $63.2 \%$ & $77.5 \%$ \\
\hline College graduate or more & $9.3 \%$ & $3.3 \%$ & $8.7 \%$ & $22.8 \%$ \\
\hline Sample size & $1,255,337$ & 171,858 & 137,141 & $4,444,392$ \\
\hline \multicolumn{5}{|l|}{ Women } \\
\hline No schooling & $8.2 \%$ & $10.5 \%$ & $1.4 \%$ & $1.0 \%$ \\
\hline 1-4 Years of school & $15.8 \%$ & $6.9 \%$ & $0.7 \%$ & $0.5 \%$ \\
\hline 5-6 Years of school & $23.5 \%$ & $22.0 \%$ & $1.8 \%$ & $1.3 \%$ \\
\hline 7-8 Years of school & $4.4 \%$ & $8.9 \%$ & $3.2 \%$ & $1.8 \%$ \\
\hline 9 Years of school & $19.0 \%$ & $9.9 \%$ & $4.9 \%$ & $2.8 \%$ \\
\hline 10-11 Years of school & $6.8 \%$ & $13.9 \%$ & $20.9 \%$ & $11.9 \%$ \\
\hline High school graduate & $11.2 \%$ & $16.0 \%$ & $27.5 \%$ & $26.9 \%$ \\
\hline Some College & $4.6 \%$ & $8.3 \%$ & $29.9 \%$ & $31.4 \%$ \\
\hline College Graduate & $3.6 \%$ & $2.2 \%$ & $7.1 \%$ & $15.2 \%$ \\
\hline Graduate School & $2.9 \%$ & $1.4 \%$ & $2.6 \%$ & $7.2 \%$ \\
\hline High school graduate or more & $22.3 \%$ & $28.0 \%$ & $67.1 \%$ & $80.7 \%$ \\
\hline College graduate or more & $6.5 \%$ & $3.6 \%$ & $9.7 \%$ & $22.4 \%$ \\
\hline Sample size & $1,399,495$ & 128,059 & 137,218 & $4,541,637$ \\
\hline
\end{tabular}

Notes: (1) The sample consists of all individuals ages 16-64. (2) All estimates are calculated using sample weights provided by the Census. 
Table 4

Age Distributions in Mexico and the United States

Mexico Census (2000) and U.S. Census 5\% PUMS (2000)

\begin{tabular}{|c|c|c|c|c|}
\hline & Mexico & $\begin{array}{r}\text { Mexican } \\
\text { Immigrants } \\
\text { in U.S. }\end{array}$ & $\begin{array}{r}\text { Mexican } \\
\text { Natives } \\
\text { in U.S. }\end{array}$ & $\begin{array}{l}\text { U.S. } \\
\text { Total }\end{array}$ \\
\hline \multicolumn{5}{|l|}{ Men } \\
\hline Ages $16-19$ & $14.9 \%$ & $6.0 \%$ & $17.6 \%$ & $9.0 \%$ \\
\hline Ages $20-24$ & $16.1 \%$ & $15.5 \%$ & $18.2 \%$ & $10.7 \%$ \\
\hline Ages $25-29$ & $14.4 \%$ & $18.0 \%$ & $14.2 \%$ & $10.7 \%$ \\
\hline Ages 30-34 & $12.6 \%$ & $16.7 \%$ & $11.3 \%$ & $11.3 \%$ \\
\hline Ages 35-39 & $11.2 \%$ & $14.6 \%$ & $10.8 \%$ & $12.7 \%$ \\
\hline Ages $40-44$ & $9.3 \%$ & $10.9 \%$ & $9.1 \%$ & $12.5 \%$ \\
\hline Ages $45-49$ & $7.2 \%$ & $7.7 \%$ & $7.0 \%$ & $11.0 \%$ \\
\hline Ages 50-54 & $6.0 \%$ & $5.1 \%$ & $5.5 \%$ & $9.4 \%$ \\
\hline Ages 55-59 & $4.5 \%$ & $3.4 \%$ & $3.6 \%$ & $7.1 \%$ \\
\hline Ages $60-64$ & $3.9 \%$ & $2.3 \%$ & $2.8 \%$ & $5.7 \%$ \\
\hline Age (Mean) & 33.5 & 34.2 & 32.2 & 37.9 \\
\hline Sample size & $1,255,337$ & 171,858 & 137,141 & $4,444,392$ \\
\hline \multicolumn{5}{|l|}{ Women } \\
\hline Ages $16-19$ & $14.1 \%$ & $4.2 \%$ & $17.2 \%$ & $8.5 \%$ \\
\hline Ages $20-24$ & $16.5 \%$ & $12.6 \%$ & $17.2 \%$ & $10.2 \%$ \\
\hline Ages $25-29$ & $14.8 \%$ & $16.9 \%$ & $13.6 \%$ & $10.4 \%$ \\
\hline Ages $30-34$ & $12.8 \%$ & $16.5 \%$ & $11.2 \%$ & $11.0 \%$ \\
\hline Ages 35-39 & $11.4 \%$ & $15.0 \%$ & $11.1 \%$ & $12.7 \%$ \\
\hline Ages 40-44 & $9.2 \%$ & $11.8 \%$ & $9.5 \%$ & $12.5 \%$ \\
\hline Ages $45-49$ & $7.1 \%$ & $8.7 \%$ & $7.5 \%$ & $11.2 \%$ \\
\hline Ages 50-54 & $5.9 \%$ & $6.4 \%$ & $5.8 \%$ & $9.7 \%$ \\
\hline Ages 55-59 & $4.5 \%$ & $4.5 \%$ & $3.8 \%$ & $7.6 \%$ \\
\hline Ages 60-64 & $3.8 \%$ & $3.5 \%$ & $3.2 \%$ & $6.2 \%$ \\
\hline Age (Mean) & 33.5 & 35.9 & 32.7 & 38.5 \\
\hline Sample size & $1,399,495$ & 128,059 & 137,218 & $4,541,637$ \\
\hline
\end{tabular}

Notes: (1) The sample consists of all individuals ages 16-64. (2) All estimates are calculated using sample weights provided by the Census. 
Table 5A

Probability of Self-Employment Regressions (Men)

Mexico

With Without

United States

Agriculture Agriculture

With Without

\begin{tabular}{|c|c|c|c|c|}
\hline & Agriculture & Agriculture & Agriculture & Agriculture \\
\hline \multirow[t]{2}{*}{ Intercept } & 0.1362 & 0.0523 & -0.01506 & -0.01087 \\
\hline & $(0.0009)$ & $(0.0011)$ & $(0.0026)$ & $(0.0027)$ \\
\hline \multirow[t]{2}{*}{ Age 20-24 } & 0.0376 & 0.0405 & 0.00602 & 0.00635 \\
\hline & $(0.0005)$ & $(0.0005)$ & $(0.0016)$ & $(0.0016)$ \\
\hline \multirow[t]{2}{*}{ Age 25-29 } & 0.0889 & 0.099 & 0.02168 & 0.02173 \\
\hline & $(0.0005)$ & $(0.0005)$ & $(0.0015)$ & $(0.0015)$ \\
\hline \multirow[t]{2}{*}{ Age $30-34$} & 0.1372 & 0.1552 & 0.04239 & 0.04215 \\
\hline & $(0.0006)$ & $(0.0006)$ & $(0.0015)$ & (0.0015) \\
\hline \multirow[t]{2}{*}{ Age 35-39 } & 0.1649 & 0.1873 & 0.06925 & 0.06773 \\
\hline & $(0.0006)$ & $(0.0006)$ & $(0.0015)$ & $(0.0015)$ \\
\hline \multirow[t]{2}{*}{ Age 40-44 } & 0.2026 & 0.2284 & 0.08796 & 0.0858 \\
\hline & $(0.0007)$ & $(0.0007)$ & $(0.0015)$ & $(0.0015)$ \\
\hline \multirow[t]{2}{*}{ Age $45-49$} & 0.2366 & 0.2575 & 0.10429 & 0.10072 \\
\hline & $(0.0008)$ & $(0.0008)$ & $(0.0015)$ & $(0.0015)$ \\
\hline \multirow[t]{2}{*}{ Age $50-54$} & 0.273 & 0.2897 & 0.11035 & 0.10629 \\
\hline & $(0.0008)$ & $(0.0009)$ & $(0.0016)$ & $(0.0016)$ \\
\hline \multirow[t]{2}{*}{ Age $55-59$} & 0.3112 & 0.3211 & 0.13432 & 0.12749 \\
\hline & $(0.0010)$ & $(0.0011)$ & $(0.0016)$ & (0.0016) \\
\hline \multirow[t]{2}{*}{ Age 60-64 } & 0.3639 & 0.3632 & 0.16375 & 0.15197 \\
\hline & $(0.0012)$ & $(0.0014)$ & $(0.0018)$ & (0.0018) \\
\hline \multirow[t]{2}{*}{ 1-4 years schooling } & 0.0031 & 0.0167 & -0.00578 & -0.00241 \\
\hline & $(0.0008)$ & $(0.0011)$ & $(0.0035)$ & $(0.0037)$ \\
\hline \multirow[t]{2}{*}{$5-6$ years schooling } & -0.0233 & 0.016 & 0.00395 & 0.00451 \\
\hline & $(0.0008)$ & $(0.0010)$ & $(0.0027)$ & $(0.0028)$ \\
\hline \multirow[t]{2}{*}{ 7-8 years schooling } & -0.0521 & 0.0175 & 0.04576 & 0.03453 \\
\hline & $(0.0009)$ & $(0.0011)$ & $(0.0027)$ & $(0.0027)$ \\
\hline \multirow[t]{2}{*}{9 years schooling } & -0.0683 & -0.0023 & 0.03328 & 0.02771 \\
\hline & $(0.0008)$ & $(0.0010)$ & $(0.0026)$ & $(0.0027)$ \\
\hline \multirow[t]{2}{*}{$10-11$ years schooling } & -0.0599 & 0.0174 & 0.03518 & 0.03104 \\
\hline & (0.0009) & $(0.0011)$ & $(0.0023)$ & $(0.0024)$ \\
\hline \multirow[t]{2}{*}{ High school complete } & -0.0602 & 0.0138 & 0.03231 & 0.02318 \\
\hline & $(0.0009)$ & $(0.0011)$ & $(0.0022)$ & $(0.0023)$ \\
\hline \multirow[t]{2}{*}{ Some college } & -0.0679 & 0.0068 & 0.03098 & 0.02498 \\
\hline & $(0.0010)$ & $(0.0012)$ & $(0.0022)$ & $(0.0023)$ \\
\hline \multirow[t]{2}{*}{ College complete } & -0.0659 & 0.009 & 0.03562 & 0.03073 \\
\hline & $(0.0010)$ & $(0.0012)$ & $(0.0022)$ & $(0.0023)$ \\
\hline \multirow[t]{2}{*}{ Graduate school } & -0.0381 & 0.0379 & 0.06213 & 0.06225 \\
\hline & $(0.0010)$ & $(0.0012)$ & $(0.0023)$ & $(0.0023)$ \\
\hline \multirow[t]{2}{*}{ Married } & 0.0092 & 0.0014 & 0.0195 & 0.0175 \\
\hline & $(0.0003)$ & $(0.0004)$ & $(0.0004)$ & $(0.0004)$ \\
\hline \multirow[t]{2}{*}{ Number of children } & 0.0063 & 0.0009 & 0.00548 & 0.00501 \\
\hline & $(0.0001)$ & $(0.0001)$ & $(0.0002)$ & $(0.0002)$ \\
\hline R-Square & 0.058 & 0.055 & 0.024 & 0.023 \\
\hline Weighted observations & 8497574 & 7045089 & 2893273 & 2792842 \\
\hline Dependent mean & 0.2576 & 0.2209 & 0.111 & 0.106 \\
\hline
\end{tabular}


Table 5B

Probability of Self-Employment Regressions (Women) Mexico

United States

With Without With Without

Agriculture Agriculture $\quad$ Agriculture Agriculture

\begin{tabular}{|c|c|c|c|c|}
\hline \multirow[t]{2}{*}{ Intercept } & 0.1806 & 0.1654 & 0.02462 & 0.02499 \\
\hline & $(0.0014)$ & $(0.0016)$ & $(0.0027)$ & $(0.0027)$ \\
\hline \multirow[t]{2}{*}{ Age $20-24$} & 0.0313 & 0.0323 & -0.0011 & -0.0004866 \\
\hline & $(0.0005)$ & $(0.0005)$ & $(0.0014)$ & $(0.0014)$ \\
\hline \multirow[t]{2}{*}{ Age 25-29 } & 0.0723 & 0.0738 & 0.00623 & 0.00691 \\
\hline & $(0.0006)$ & $(0.0006)$ & $(0.0014)$ & $(0.0014)$ \\
\hline \multirow[t]{2}{*}{ Age $30-34$} & 0.103 & 0.107 & 0.01977 & 0.0203 \\
\hline & $(0.0007)$ & $(0.0007)$ & $(0.0014)$ & $(0.0014)$ \\
\hline \multirow[t]{2}{*}{ Age 35-39 } & 0.1273 & 0.1316 & 0.02853 & 0.02871 \\
\hline & $(0.0008)$ & $(0.0008)$ & $(0.0014)$ & $(0.0014)$ \\
\hline \multirow[t]{2}{*}{ Age 40-44 } & 0.1567 & 0.1623 & 0.03469 & 0.03458 \\
\hline & $(0.0009)$ & $(0.0009)$ & $(0.0014)$ & $(0.0014)$ \\
\hline \multirow[t]{2}{*}{ Age 45-49 } & 0.2042 & 0.2091 & 0.03967 & 0.03942 \\
\hline & $(0.0011)$ & $(0.0011)$ & $(0.0014)$ & $(0.0014)$ \\
\hline \multirow[t]{2}{*}{ Age $50-54$} & 0.2537 & 0.2577 & 0.04605 & 0.04567 \\
\hline & $(0.0013)$ & $(0.0013)$ & $(0.0014)$ & $(0.0014)$ \\
\hline \multirow[t]{2}{*}{ Age 55-59 } & 0.3183 & 0.3249 & 0.0574 & 0.0563 \\
\hline & $(0.0018)$ & $(0.0018)$ & $(0.0015)$ & $(0.0014)$ \\
\hline \multirow[t]{2}{*}{ Age 60-64 } & 0.4077 & 0.4171 & 0.06858 & 0.06667 \\
\hline & $(0.0023)$ & $(0.0024)$ & $(0.0016)$ & $(0.0016)$ \\
\hline \multirow[t]{2}{*}{$1-4$ years schooling } & -0.0579 & -0.0532 & 0.00309 & 0.00771 \\
\hline & $(0.0015)$ & $(0.0017)$ & $(0.0039)$ & $(0.0040)$ \\
\hline \multirow[t]{2}{*}{ 5-6 years schooling } & -0.1099 & -0.1023 & -0.00217 & -0.0005397 \\
\hline & $(0.0014)$ & $(0.0015)$ & $(0.0030)$ & $(0.0031)$ \\
\hline \multirow[t]{2}{*}{ 7-8 years schooling } & -0.1388 & -0.1266 & 0.00313 & 0.00062506 \\
\hline & $(0.0016)$ & $(0.0017)$ & $(0.0029)$ & $(0.0029)$ \\
\hline \multirow[t]{2}{*}{9 years schooling } & -0.1604 & -0.1479 & -0.00491 & -0.00586 \\
\hline & $(0.0014)$ & $(0.0015)$ & $(0.0028)$ & $(0.0028)$ \\
\hline \multirow[t]{2}{*}{$10-11$ years schooling } & -0.1707 & -0.1566 & -0.00683 & -0.00762 \\
\hline & $(0.0015)$ & $(0.0016)$ & $(0.0025)$ & $(0.0025)$ \\
\hline \multirow[t]{2}{*}{ High school complete } & -0.1946 & -0.1808 & -0.01191 & -0.01326 \\
\hline & $(0.0014)$ & $(0.0015)$ & $(0.0024)$ & $(0.0024)$ \\
\hline \multirow[t]{2}{*}{ Some college } & -0.2203 & & -0.01005 & -0.01108 \\
\hline & $(0.0015)$ & $(0.0016)$ & $(0.0024)$ & $(0.0024)$ \\
\hline \multirow[t]{2}{*}{ College complete } & -0.2251 & -0.2124 & -0.01262 & -0.01348 \\
\hline & $(0.0015)$ & $(0.0016)$ & $(0.0024)$ & $(0.0024)$ \\
\hline \multirow[t]{2}{*}{ Graduate school } & -0.2012 & -0.1883 & -0.0076 & -0.00754 \\
\hline & $(0.0015)$ & $(0.0016)$ & $(0.0024)$ & $(0.0024)$ \\
\hline \multirow[t]{2}{*}{ Married } & 0.0956 & 0.0937 & 0.01784 & 0.01677 \\
\hline & $(0.0005)$ & $(0.0005)$ & $(0.0003)$ & $(0.0003)$ \\
\hline \multirow[t]{2}{*}{ Number of children } & 0.0019 & 0.0015 & 0.00303 & 0.00299 \\
\hline & $(0.0001)$ & $(0.0001)$ & $(0.0002)$ & $(0.0002)$ \\
\hline R-Square & 0.111 & 0.108 & 0.009 & 0.009 \\
\hline Weighted observations & 3307417 & 3189182 & 2096007 & 2076656 \\
\hline Dependent mean & 0.1698 & 0.164 & 0.056 & 0.055 \\
\hline
\end{tabular}


Table 6

Self-Employment Status Regressions in Mexico

MALES

With ag With ag

Own acct Employer

Intercept

Age 20-24

Age 25-29

Age 30-34

Age 35-39

Age 40-44

Age 45-49

Age 50-54

Age 55-59

Age 60-64

1-4 years schooling

$-0.0038^{*} \quad 0.0068^{*}$

$(0.0008) \quad(0.0002)$

5-6 years schooling $\quad-0.0410^{*} \quad 0.0176^{*}$

$(0.0008) \quad(0.0002)$

$7-8$ years schooling $-0.0743^{*} \quad 0.0222^{*}$

(0.0009) (0.0003)

9 years schooling

$-0.0925^{*} \quad 0.0242^{*}$

$(0.0008) \quad(0.0002)$

$10-11$ years schooling $-0.0934^{*} 0.0335^{*}$

$(0.0009) \quad(0.0003)$

\section{FEMALES}

With ag With ag

Own acct Employer

$0.1978^{*}-0.0172^{*}$

$(0.0014) \quad(0.0003)$

$0.0326^{*}-0.0013^{*}$

$(0.0005) \quad(0.0001)$

$0.0698^{*} \quad 0.0025^{*}$

(0.0006) (0.0002)

$0.0956^{*} \quad 0.0073^{*}$

(0.0007) (0.0002)

$0.1116^{*} \quad 0.0157^{*}$

$(0.0007) \quad(0.0003)$

$0.1359^{*} \quad 0.0208^{*}$

(0.0008) (0.0003)

$0.1765^{\star} \quad 0.0276^{*}$

(0.0010) (0.0004)

$0.2172^{*} \quad 0.0364^{*}$

(0.0013) (0.0005)

$0.2760^{*} \quad 0.0424^{*}$

$(0.0017) \quad(0.0007)$

$0.3613^{*} \quad 0.0464^{*}$

(0.0023) $\quad(0.0010)$

$-0.0662^{*} \quad 0.0084^{*}$

(0.0015) (0.0003)

$-0.1257^{*} \quad 0.0157^{*}$

(0.0014) (0.0003)

$-0.1582^{*} \quad 0.0194^{*}$

(0.0016) (0.0004)

$-0.1809^{*} \quad 0.0205^{*}$

(0.0014) (0.0003)

$-0.1931^{*} \quad 0.0224^{*}$

$(0.0015) \quad(0.0004)$ 


\begin{tabular}{|c|c|c|c|c|}
\hline High school complete & $\begin{array}{l}-0.1042^{*} \\
(0.0008)\end{array}$ & $\begin{array}{l}0.0440^{*} \\
\quad(0.0003)\end{array}$ & $\begin{array}{r}-0.2204^{*} \\
(0.0014)\end{array}$ & $\begin{array}{l}0.0258^{*} \\
\quad(0.0004)\end{array}$ \\
\hline Some college & $\begin{array}{r}-0.1254^{*} \\
(0.0010)\end{array}$ & $\begin{array}{l}0.0576^{*} \\
\quad(0.0005)\end{array}$ & $\begin{array}{l}-0.2509^{*} \\
(0.0015)\end{array}$ & $\begin{array}{l}0.0306^{*} \\
\quad(0.0005)\end{array}$ \\
\hline College complete & $\begin{array}{r}-0.1472^{*} \\
(0.0009)\end{array}$ & $\begin{array}{l}0.0813^{*} \\
\quad(0.0005)\end{array}$ & $\begin{array}{r}-0.2586^{*} \\
(0.0014)\end{array}$ & $\begin{array}{l}0.0335^{*} \\
\quad(0.0005)\end{array}$ \\
\hline Graduate school & $\begin{array}{r}-0.1295^{\star} \\
(0.0009)\end{array}$ & $\begin{array}{l}0.0914^{*} \\
\quad(0.0005)\end{array}$ & $\begin{array}{r}-0.2389^{*} \\
\quad(0.0015)\end{array}$ & $\begin{array}{l}0.0377^{*} \\
\quad(0.0005)\end{array}$ \\
\hline Married & $\begin{array}{l}0.0000^{*} \\
(0.0003)\end{array}$ & $\begin{array}{l}0.0092^{*} \\
\quad(0.0001)\end{array}$ & $\begin{array}{l}0.0814^{*} \\
\quad(0.0005)\end{array}$ & $\begin{array}{l}0.0142^{*} \\
\quad(0.0002)\end{array}$ \\
\hline Number of children & $\begin{array}{l}0.0068^{*} \\
(0.0001)\end{array}$ & $\begin{array}{r}-0.0005^{*} \\
(0.0000)\end{array}$ & $\begin{array}{l}0.0020^{*} \\
\quad(0.0001)\end{array}$ & $\begin{array}{r}-0.0001 \sim \\
0.0000\end{array}$ \\
\hline -square & 0.053 & 0.029 & 0.106 & 0.015 \\
\hline Weighted observations & 8497574 & 8497574 & 3307417 & 3307417 \\
\hline Dependent mean & 0.2263 & 0.0313 & 0.151 & 0.0188 \\
\hline
\end{tabular}

Notes: Sample restricted to 16-64 year olds working 35 or more hours per week.

Standard errors in parentheses. ${ }^{*}$ indicates significant at .01 level. $\sim$ indicates signifciant at .05 level 
Table 7A

Predicted Male Self-Employment Rates for Mexico and the United States

All Industries

Mean Characteristics from:

Mexico U.S. Total

Difference

Coefficients Mexico

$25.8 \%$

$27.1 \%$

$-1.3 \%$

from:

U.S. Total

$8.4 \%$

$11.1 \%$

$-2.7 \%$

Difference

$17.3 \%$

$16.0 \%$

$14.6 \%$

Non-Agriculture

Mean Characteristics from:

Mexico U.S. Total Difference

Coefficients Mexico

$22.1 \%$

$26.7 \%$

$-4.6 \%$

from:

U.S. Total

$8.2 \%$

$10.6 \%$

$-2.3 \%$

Difference

$13.9 \%$

$16.1 \%$

$11.5 \%$

Notes: (1) The sample consists of individuals ages 16-64 who work 35 or more hours per week. (2) All estimates are calculated using sample weights provided by the Census. (3) Coefficient estimates are reported in Table 5. 
Table 7B

Predicted Female Self-Employment Rates for Mexico and the United States

All Industries

Mean Characteristics from:

Mexico U.S. Total

Difference

Coefficients Mexico

$17.0 \%$

$18.9 \%$

$-1.9 \%$

from:

U.S. Total

$4.9 \%$

$5.6 \%$

$-0.8 \%$

Difference

$12.1 \%$

$13.3 \%$

$11.3 \%$

Non-Agriculture

Mean Characteristics from:

Mexico U.S. Total Difference

Coefficients Mexico

$16.4 \%$

$19.0 \%$

$-2.6 \%$

from:

U.S. Total

$4.9 \%$

$5.5 \%$

$-0.7 \%$

Difference

$11.5 \%$

$13.5 \%$

$10.9 \%$

Notes: (1) The sample consists of individuals ages 16-64 who work 35 or more hours per week. (2) All estimates are calculated using sample weights provided by the Census. (3) Coefficient estimates are reported in Table 5. 
Table 8

Predicted Self-Employment Rates in the United Sates U.S. Census (2000)

\begin{tabular}{|c|c|c|c|c|}
\hline \multirow[b]{2}{*}{ Explanatory Variables } & \multicolumn{4}{|c|}{ Specification } \\
\hline & $(1)$ & (2) & (3) & (4) \\
\hline Sample & Men & Men & Women & Women \\
\hline Industries & All & Non-Agric. & All & Non-Agric. \\
\hline U.S. Self-Employment Rate & $11.1 \%$ & $10.6 \%$ & $5.6 \%$ & $5.5 \%$ \\
\hline \multicolumn{5}{|l|}{ Mexican Immigrants } \\
\hline Actual self-employment rate & $6.0 \%$ & $6.2 \%$ & $6.1 \%$ & $6.2 \%$ \\
\hline Predicted self-employment rate & $8.3 \%$ & $8.0 \%$ & $6.1 \%$ & $6.1 \%$ \\
\hline
\end{tabular}


Table 9

Language and Enclave Effects (U.S. Census 2000)

Males

(2)

(3)

(4)

English Language

ability

(1)

$0.0196 \quad 0.0278$

(0.0017) (0.0026)

$0.00083 \quad 0.00877$

$(0.0027) \quad(0.0041)$

Percentage Latino-

origin population,

PUMA
Language * \% Latino
population

$0.00058 \quad 0.00087$

$-0.00011 \quad 0.00016$

$(0.0001) \quad(0.0002)$

$(0.0001) \quad(0.0002)$

$-0.00053$

$-0.00053$

$(0.0001)$

(0.0002)

Psudo-R-square

$0.036 \quad 0.036$

$0.016 \quad 0.017$

Weighted observations

Dependent mean

$2644810 \quad 2644810$

$0.061 \quad 0.06$

$991715 \quad 991715$

$0.055 \quad 0.055$

